Central Washington University

ScholarWorks@CWU

All Master's Theses

Master's Theses

Summer 2008

\title{
Middle Crustal Ductile Deformation Patterns in Southern Tibet: Insights from Vorticity Studies in Mabja Dome
}

Jackie Langille

Central Washington University

Follow this and additional works at: https://digitalcommons.cwu.edu/etd

Part of the Geochemistry Commons, Geology Commons, and the Geomorphology Commons

\section{Recommended Citation}

Langille, Jackie, "Middle Crustal Ductile Deformation Patterns in Southern Tibet: Insights from Vorticity Studies in Mabja Dome" (2008). All Master's Theses. 1418.

https://digitalcommons.cwu.edu/etd/1418

This Thesis is brought to you for free and open access by the Master's Theses at ScholarWorks@CWU. It has been accepted for inclusion in All Master's Theses by an authorized administrator of ScholarWorks@CWU. For more information, please contact scholarworks@cwu.edu. 


\section{MIDDLE CRUSTAL DUCTILE DEFORMATION PATTERNS IN SOUTHERN \\ TIBET: INSIGHTS FROM VORTICITY STUDIES \\ IN MABJA DOME}

A Thesis
Presented to
The Graduate Faculty
Central Washington University
In Partial Fulfillment
of the Requirements for the Degree
Master of Science
Geology

by

Jackie Langille

June 2008 


\title{
CENTRAL WASHINGTON UNIVERSITY
}

Graduate Studies

We hereby approve the thesis of

\author{
Jackie Langille
}

Candidate for the degree of Master of Science

APPROVED FOR THE GRADUATE FACULTY

Dr. Jeffrey Lee, Committee Chair

Dr. Wendy Bohrson

Dr. Charles Rubin

Dean of Graduate Studies 


\begin{abstract}
MIDDLE CRUSTAL DUCTILE DEFORMATION PATTERNS IN SOUTHERN

TIBET: INSIGHTS FROM VORTICITY STUDIES

IN MABJA DOME

by

Jackie Langille

June 2008
\end{abstract}

Mabja Dome, southern Tibet, exposes mid-crustal rocks proposed to have originated from a southward flowing mid-crustal channel. Kinematic, mean kinematic vorticity $\left(W_{\mathrm{m}}\right)$, and metamorphic petrography analyses on these mid-crustal rocks were performed to test this hypothesis. Kinematic indicators show a transition with structural depth from top-north and top-south shear to solely top-south shear. Along the

northernmost transects, $W_{\mathrm{m}}$ in schists and orthogneisses range from $0.52-0.84(63-36 \%$ pure shear). $W_{\mathrm{m}}$ for quartzites ranges from $0.9-0.99$ (27-1\% pure shear). Deformation temperatures increase from $\sim 450{ }^{\circ} \mathrm{C}$ in the chloritoid-zone to $\sim 700{ }^{\circ} \mathrm{C}$ in the sillimanitezone and were recorded between $\sim 35-16 \mathrm{Ma}$. These patterns exhibit a complex flow regime characterized by: (1) opposing shear sense driven by heterogeneous viscosity and/or channel thickness, (2) broad top-south shear along the Main Central Thrust, (3) simple shear partitioned into weaker quartzite horizons, and (4) an increase in lithostatic load with depth. 


\section{ACKNOWLEDGMENTS}

I received assistance from many helpful people and organizations while working on this project. Funding was provided by generous grants from the Geological Society of America, CWU Department of Graduate Studies, and Sigma Xi. Additional funding for travel to conferences in order to present this work was provided by the CWU Department of Geological Sciences, the CWU Department of Graduate Studies, and Jeffrey Lee. I wish to thank my committee members Wendy Bohrson and Charlie Rubin for their input and support of my research. Of course, I must thank my advisor Jeffrey Lee for his exceptional guidance and support while working on this project. Thanks to Bradley Hacker and Gareth Seward for their collaboration and the use of their facilities at the University of California, Santa Barbara. Thanks also to Rick Law, Virginia Tech, and Micah Jessup, University of Tennessee, for discussions about vorticity measurements and their work on the Everest massif. Thanks to Vicky Potts and Craig Scrivner who helped me in times of logistical and technical troubles. In addition, I would like to thank all of the members of the Department of Geological Sciences, my fellow students, my family, and my husband for their support and encouragement throughout this project. 


\section{TABLE OF CONTENTS}

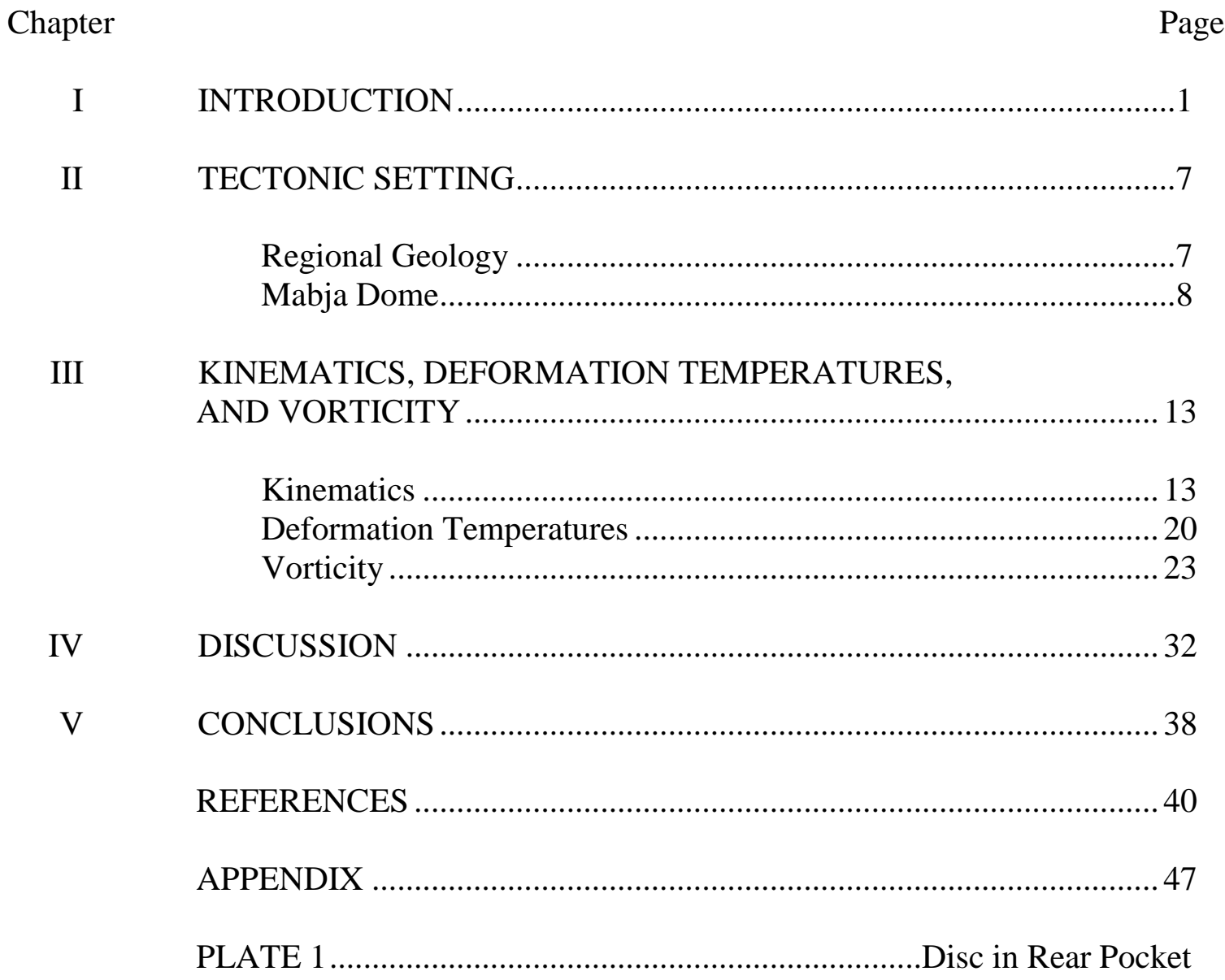




\section{LIST OF FIGURES}

Figure

1 Regional tectonic map of the south-central Himalayan orogeny ........................ 1

2 Models of extrusion/exhumation of middle crustal rocks of the GHS ................3

3 Schematic velocity profile of idealized channel flow in the middle crust of southern Tibet ............................................................................... 4

$4 \quad$ Vorticity and deformation temperature sample locations ...............................

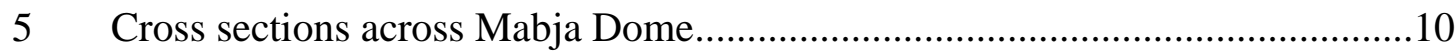

6 Photomicrographs of microstructures and quartz and feldspar

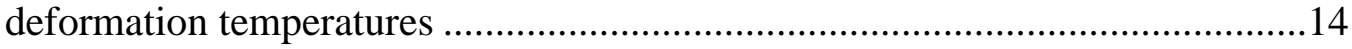

7 Quartz lattice-preferred orientation (LPO) patterns and associated

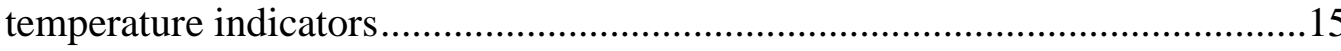

8 EBSD-generated oriented quartz LPO patterns from the A-A'-A',

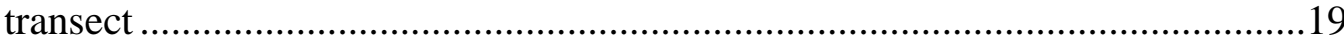

9 Estimated deformation temperatures with error bars for schists, orthogneisses, and quartzites

10 Rotation of elliptical porphyroblasts as a result of a combination of simple and pure shear.

11 Representative rigid grain net plots of porphyroblast aspect ratios vs. the angle between the porphyroblast long axis and macroscopic foliation

12 Grain-shape foliation plots of the angle $(\theta)$ between the quartz long axis and flow plane vs. frequency.

13 Vorticity and percent pure shear for schists, orthogneisses, and quartzites

14 Contour map of the average percent pure shear estimated for schists and orthogneisses across a portion of Mabja Dome

15 Temperature-time plot showing cooling histories for deformed 


\section{LIST OF FIGURES (continued)}

Figure

Page

migmatites and pegmatites and undeformed granites in Mabja Dome...............33

16 Interpretation of the velocity profile within the mid-crustal rocks

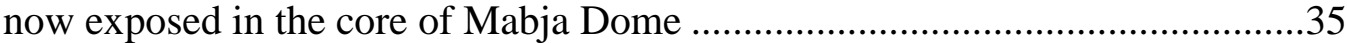




\section{CHAPTER I}

\section{INTRODUCTION}

The Himalayan orogen records Eocene to Holocene continental collision and convergence between the Indian and the Eurasian plates. Profound crustal shortening and thickening resulted in the formation of one of the most impressive orogenic belts on Earth: the Himalaya (Fig. 1), with a length of $\sim 2500 \mathrm{~km}$ and 14 peaks over $8000 \mathrm{~m}$ in elevation, and the Tibetan plateau (Fig. 1), Earth's largest plateau, which covers $>5 \times 10^{6}$ $\mathrm{km}^{2}$ and has an average elevation of $\sim 5000 \mathrm{~m}$ (Fielding et al., 1994).

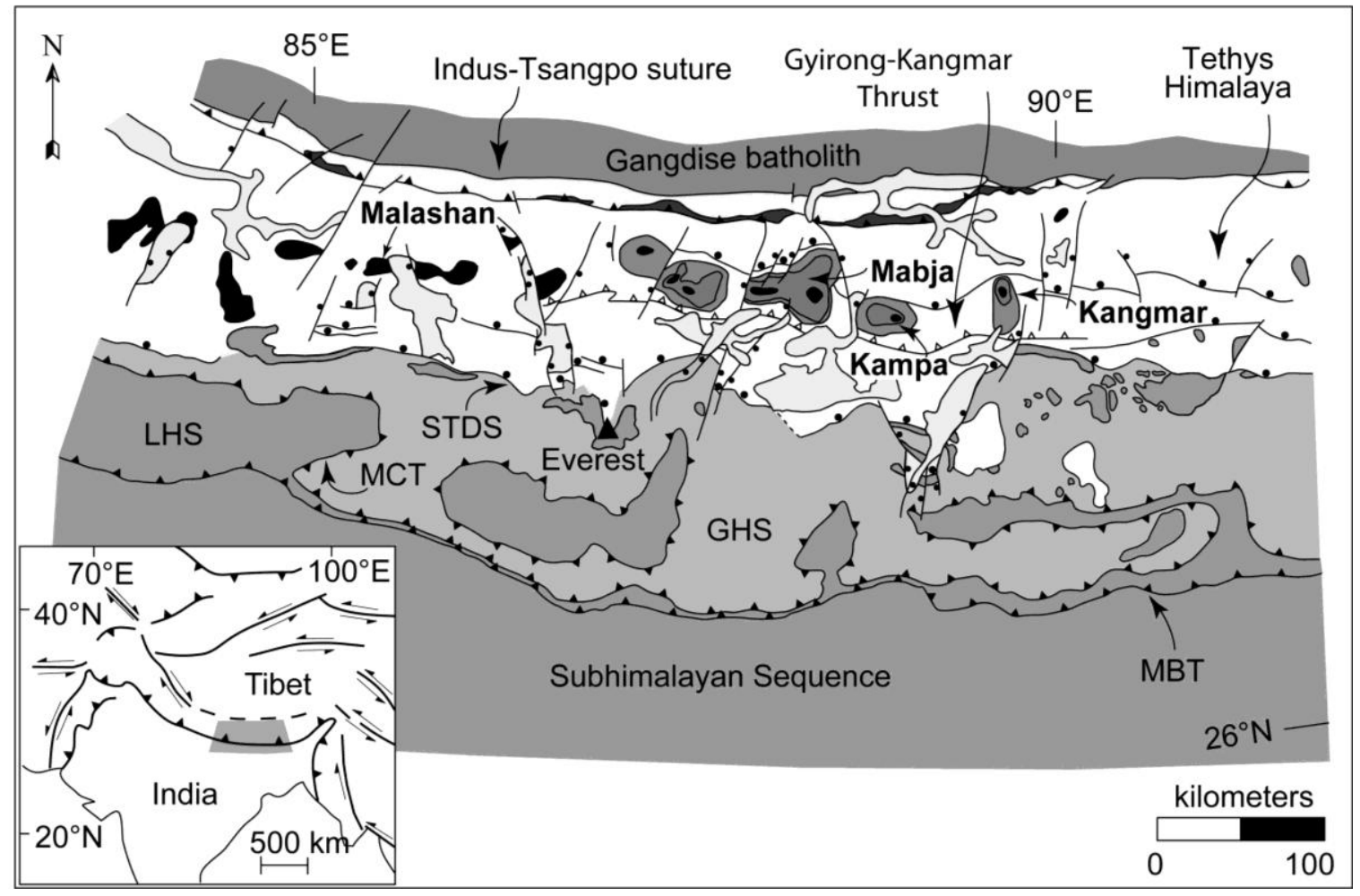

Figure 1. Regional tectonic map of the south-central Himalayan orogeny. The leucogranites and high and low grade metamorphic rocks of the North Himalayan gneiss domes (bold), including Mabja Dome, are shown with respect to major geologic features such as the Greater Himalayan Sequence (GHS), the Lesser Himalayan Sequence (LHS), the Main Central Thrust (MCT), and the South Tibetan Detachment System (STDS). Modified from Lee et al. (2004). 
Extensive geologic and geophysical research over the last 15-20 years has focused on characterizing: (1) the development and outward growth of the Tibetan Plateau; (2) the development of partial melt zones interpreted to reside in the present-day middle crust of Tibet; (3) the development of structures along the southern margin of the plateau including the broadly coeval South Tibetan Detachment System (STDS) and Main Central Thrust (MCT) that bound the Greater Himalayan Sequence (GHS), which is composed of high-grade metamorphic rocks exposed in the Himalaya (Fig. 1); (4) southward extrusion of the GHS; and (5) focused erosion along the southern margin of the plateau (e.g., Grujic et al., 1996, 2002; Vannay and Grasemann, 1998; Grasemann et al., 1999; Beaumont et al., 2001, 2004, 2006). Several models have been formulated that describe the predicted patterns of ductile flow and exhumation of middle crustal rocks during the development of the Himalayan-Tibetan orogenic belt. These models can be divided into thermal-mechanical and geometric-kinematic (non-thermal) models (Fig. 2).

Beaumont et al. $(2001,2004,2006)$ developed a set of transient, plane-strain, coupled thermal-mechanical finite-element models in which the GHS represents a 15-30 km-thick, hot, low-viscosity middle crustal channel that extruded southward from beneath southern Tibet toward the orogenic front during north-south convergence (Model 1). Flow begins after the crust has been tectonically thickened and the middle crust experiences a reduction in viscosity due to mantle heat flux and radiogenic heating. Flow and extrusion of the low-viscosity tabular body of middle crust is driven by a horizontal gravitational potential-energy gradient produced by the topographic and crustal thickness differences between the Tibetan Plateau and its margins, and focused erosion along the 
A

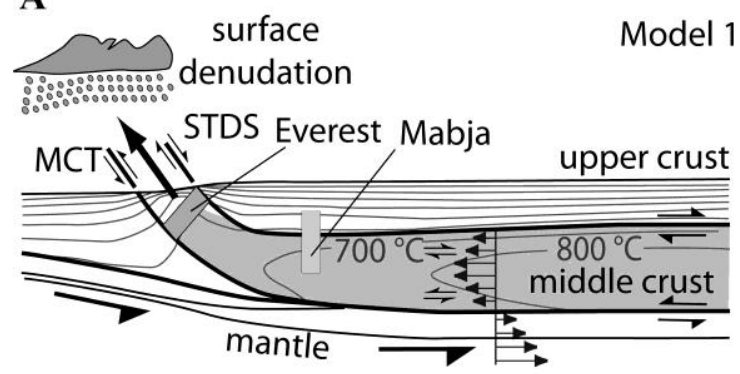

B

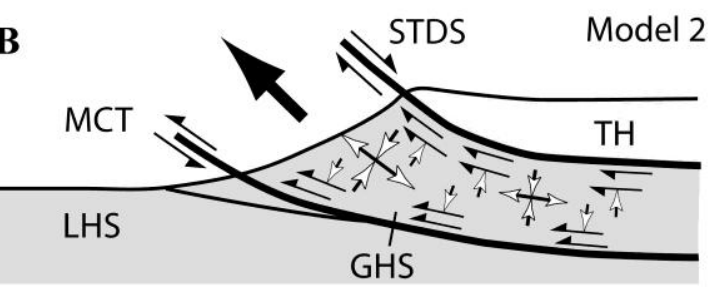

C

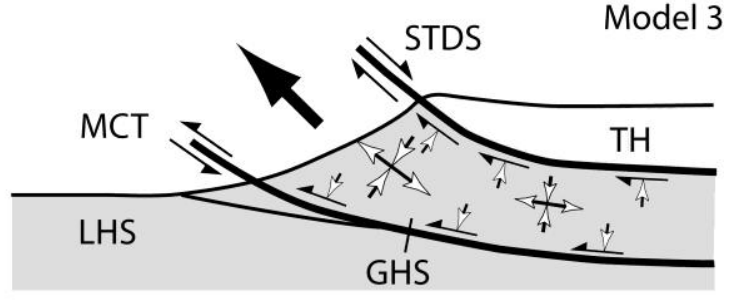

simple shear general shear (pure \&
simple shear)

Figure 2. Models of extrusion/exhumation of middle crustal rocks of the GHS. (A) Schematic diagram showing a southward flowing low viscosity middle crustal channel (gray region) bounded between the STDS and the MCT. Predicted locations of middle crustal rocks exposed in Mabja Dome and of the GHS exposed in the Everest region prior to exhumation are shown. Arrows indicate velocity vectors. Modified from Beaumont et al. (2004) and Godin et al. (2006). (B) Extrusion of a ductile block deforming by opposing simple shear at the boundaries, general shear toward the middle, and pure shear within the center. TH, Tethys Himalaya. Modified from Grujic et al. (2002). (C) Extrusion of a ductile block deforming by opposing general shear at the boundaries and pure shear within the middle. Modified from Vannay and Grasemann (2001).

southern flank of the high Himalaya (e.g., Beaumont et al., 2001, 2004; Hodges et al., 2001). The low-viscosity channel is bounded above and below by normal-sense (STDS) and thrust-sense (MCT) shear zones, respectively, that separate the channel from higher viscosity material above and below (Beaumont et al., 2001, 2004). This model predicts opposing simple shear flow at the boundaries and an increasing component of pure shear flow toward the core of the channel (Fig. 2A).

Field observations combined with microstructural and quartz petrofabric data from the lower portion of the GHS exposed in Bhutan led Grujic et al. (2002) to 
reformulate their 1996 model (Grujic et al., 1996) by postulating that a 10-15 km-thick middle crustal GHS layer or channel extends for $>200 \mathrm{~km}$ northward beneath Tibet (Model 2; Fig. 2B). In this revised model, channel flow is characterized by combined Couette and Poiseuille flow (Fig. 3). Couette flow develops between rigid plates moving relative to one another and is characterized by simple shear (high vorticity number) across the channel. Poiseuille flow develops between stationary rigid plates in which a horizontal gradient in lithostatic pressure produces the highest velocities in the center of the channel and decreasing, but opposite shear velocities toward the top and bottom of the channel. Poiseuille flow is characterized by simple shear (high vorticity number) at the top and bottom of the channel, decreasing vorticity number (mix of simple shear and pure shear or general shear) toward the center of the channel, and pure shear (low

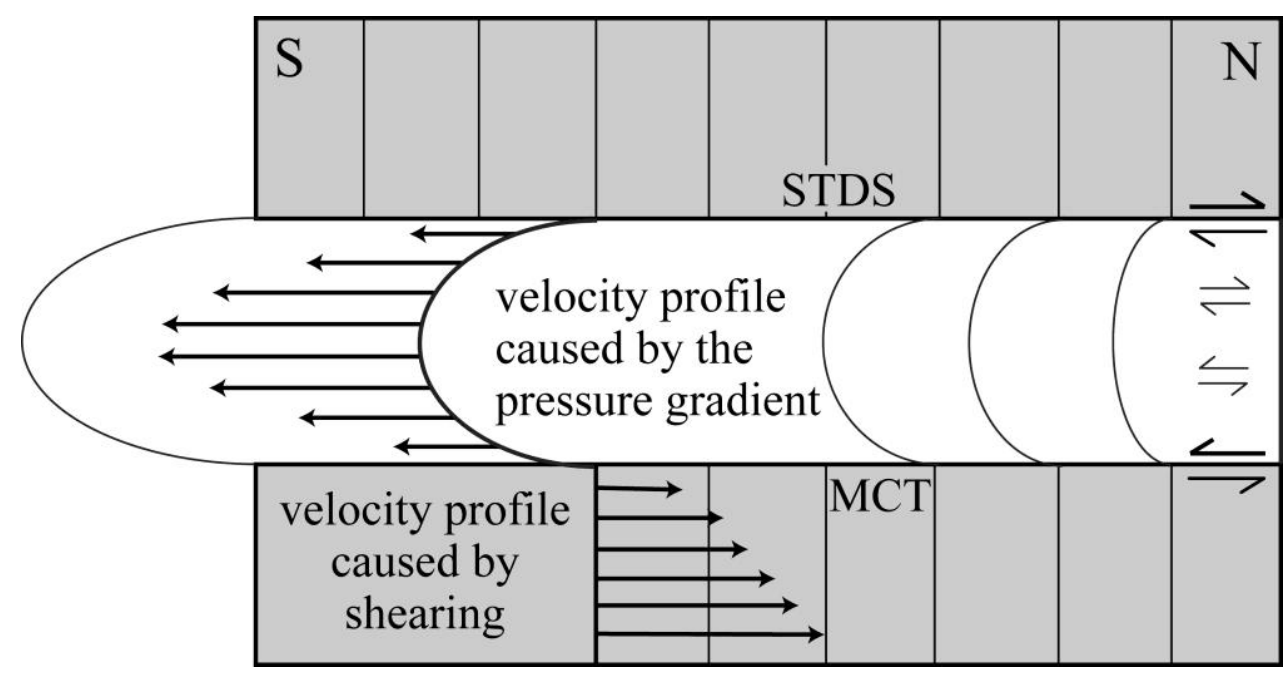

Figure 3. Schematic velocity profile of idealized channel flow in the middle crust of southern Tibet. Poiseuille flow, which is driven by a pressure gradient, and Couette flow, which is driven by shearing are shown by the velocity vectors. Vorticity $\left(W_{\mathrm{m}}\right)$ decreases (increasing pure shear) toward the center of the channel. Arrow pairs indicate shear sense. Modified from Ramsay and Huber (1987) and Grujic et al. (2002). 
vorticity number) at the center of the channel (e.g., Grujic et al., 2002). In general, laminar flow is a combination of Couette and Poiseuille flow, which can act in opposition to one another.

Based on a combination of spatially varying vorticity numbers and deformation temperatures, pressure/temperature conditions associated with inverted isograds, and mica ${ }^{40} \mathrm{Ar} /{ }^{39} \mathrm{Ar}$ cooling ages from the base of the GHS in the Sutlej Valley, northwest India (e.g., Vannay and Grasemann, 1998; Grasemann et al., 1999; Jain et al., 2000), Vannay and Grasemann (2001) proposed that the GHS defined an extruding wedge or block deformed by general shear with higher finite strains concentrated along the boundaries (Fig. 2C; Model 3). Deformation is characterized by general shear at the boundaries grading to pure shear within the center of the wedge.

These models have been derived principally from geophysical data from southern Tibet and geological data from the Himalayan front. Absent are any geological data north of the Himalaya, closer to the presumed source of flowing crust. Data on the style, vorticity, and spatial distribution of middle crustal flow in southern Tibet are essential for testing the proposed link between mid-crustal channel flow and denudation driven extrusion. Mabja Dome, southern Tibet, one of the North Himalayan gneiss domes (Fig. 1) is an ideal location for such investigations. This dome, located $\sim 100 \mathrm{~km}$ north of the high Himalaya, provides excellent exposure of an originally $\sim 35 \mathrm{~km}$-thick sequence of middle crustal rocks that preserve mid-crustal fabrics that predate doming and for which pressure/temperature/time data are well known. Detailed kinematic, microstructural, and vorticity investigations of metamorphic middle crustal rocks exposed in the core of 
Mabja Dome were performed and shows that the patterns of ductile flow in the middle crust of southern Tibet are more complicated than predicted. 


\section{CHAPTER II}

\section{TECTONIC SETTING}

\section{Regional Geology}

The North Himalayan gneiss domes are exposed within the Tethys Himalaya, approximately halfway between the Indus-Tsangpo suture to the north and the STDS to the south (Fig. 1). The Tethys Himalaya is underlain by Proterozoic to Jurassic pre-, syn-, and post-rift sedimentary rocks, a Jurassic to Cretaceous passive continental margin sedimentary sequence, and an upper Cretaceous to Eocene syn-collisional sedimentary sequence deposited on the northern margin of the Indian continent (Gansser, 1964; Le Fort, 1975; Gaetani and Garzanti, 1991; Brookfield, 1993; Liu and Einsele, 1994; Garzanti, 1999). The Tethys Himalaya is structurally complex, exhibiting Cretaceous to Holocene contractional and extensional structures in a variety of orientations. The first major north-south contractional event is Paleocene to early Eocene in age (Burg et al., 1984; Burg and Chen, 1984). A second, younger post-collisional contractional deformational event in the northern portion of the Tethys Himalaya is characterized by east-west-striking thrust faults and folds and an increase in strain towards the southvergent Gyirong-Kangmar Thrust (Fig. 1) (Burg and Chen, 1984; Ratschbacher et al., 1994). Based on mica ${ }^{40} \mathrm{Ar} /{ }^{39} \mathrm{Ar}$ cooling ages in the core of the Kangmar Dome, Burg and Chen (1984), Burg et al. (1987), and Lee et al. (2000) inferred middle Miocene slip along the Gyirong-Kangmar Thrust. These older structures are cut by middle Miocene and Pliocene to Holocene north-south-striking grabens (e.g., Armijo et al., 1986; Wu et al., 1998; Stockli et al., 2002; Dewane et al., 2006; Hager et al., 2006). 


\section{Mabja Dome}

Geologic studies have largely focused on four of the North Himalayan gneiss domes: Kangmar, Kampa, Mabja, and Malashan (Fig. 1) (e.g., Burg et al., 1984; Chen et al., 1990; Lee et al., 2000, 2002, 2004, 2006; Zhang et al., 2004; Aoya et al., 2005, 2006; Quigley et al., 2006, 2008; Lee and Whitehouse, 2007). The domes consist of a core of orthogneisses, migmatites, leucogranites, and high-grade metasedimentary rocks overlain by a progressively lower grade sedimentary rocks (e.g., Burg et al., 1984; Chen et al., 1990; Lee et al., 2000, 2004, 2006; Aoya et al., 2005, 2006; Quigley et al., 2006).

Mabja Dome is characterized by a core of migmatitic orthogneiss mantled by Paleozoic orthogneiss and metasedimentary rocks that in turn are overlain by Triassic and Jurassic metasedimentary and sedimentary rocks. During the Miocene these rocks were intruded by amphibolite dikes, a pegmatite and aplite dike swarm, two-mica granites, and a rhyolite porphyry dike (Figs. 4 and 5). These intrusions experienced deformation during and after emplacement with the exception of the two-mica granites and the rhyolite porphyry dike (Lee et al., 2004; Zhang et al., 2004).

Mabja Dome records evidence for three major deformational events: D1, characterized by north-south shortening and vertical thickening; D2, characterized by vertical thinning and north-south extension associated with moderate temperature/pressure metamorphism and intrusion of leucogranites; and a younger doming event (Lee et al., 2004, 2006). D1, the oldest deformational event, is best exposed and dominant at the highest structural levels and exhibits bedding that was horizontally shortened into east-west-trending F1 folds. Superimposed on D1 structural 


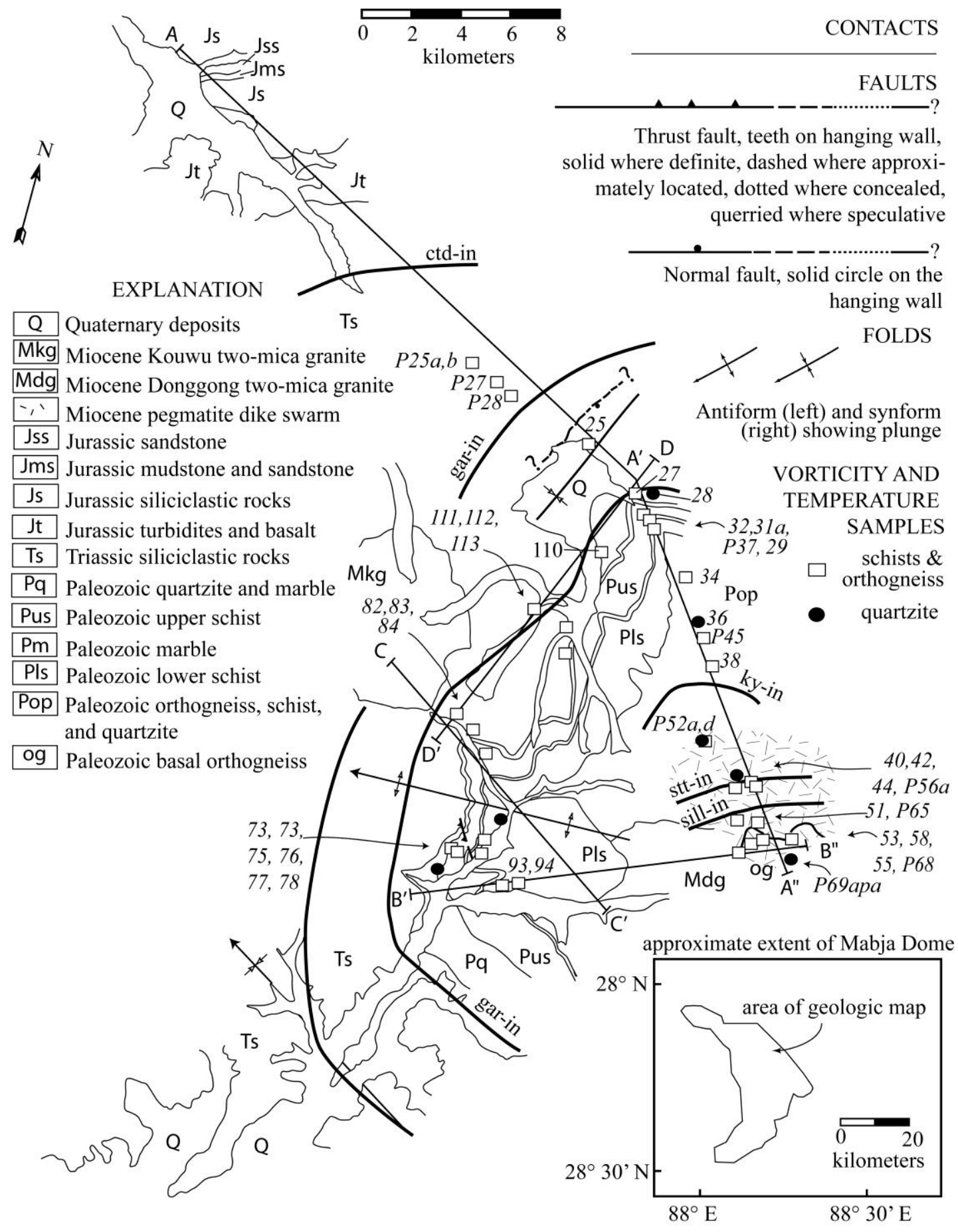

Figure 4. Vorticity and deformation temperature sample locations. Vorticity and deformation temperature sample locations in italic. Metamorphic isograds (bold lines) are included. Ctd, chloritoid; gar, garnet; ky, kyanite; stt, staurolite; sill, sillimanite. Modified from Lee et al. (2004). 

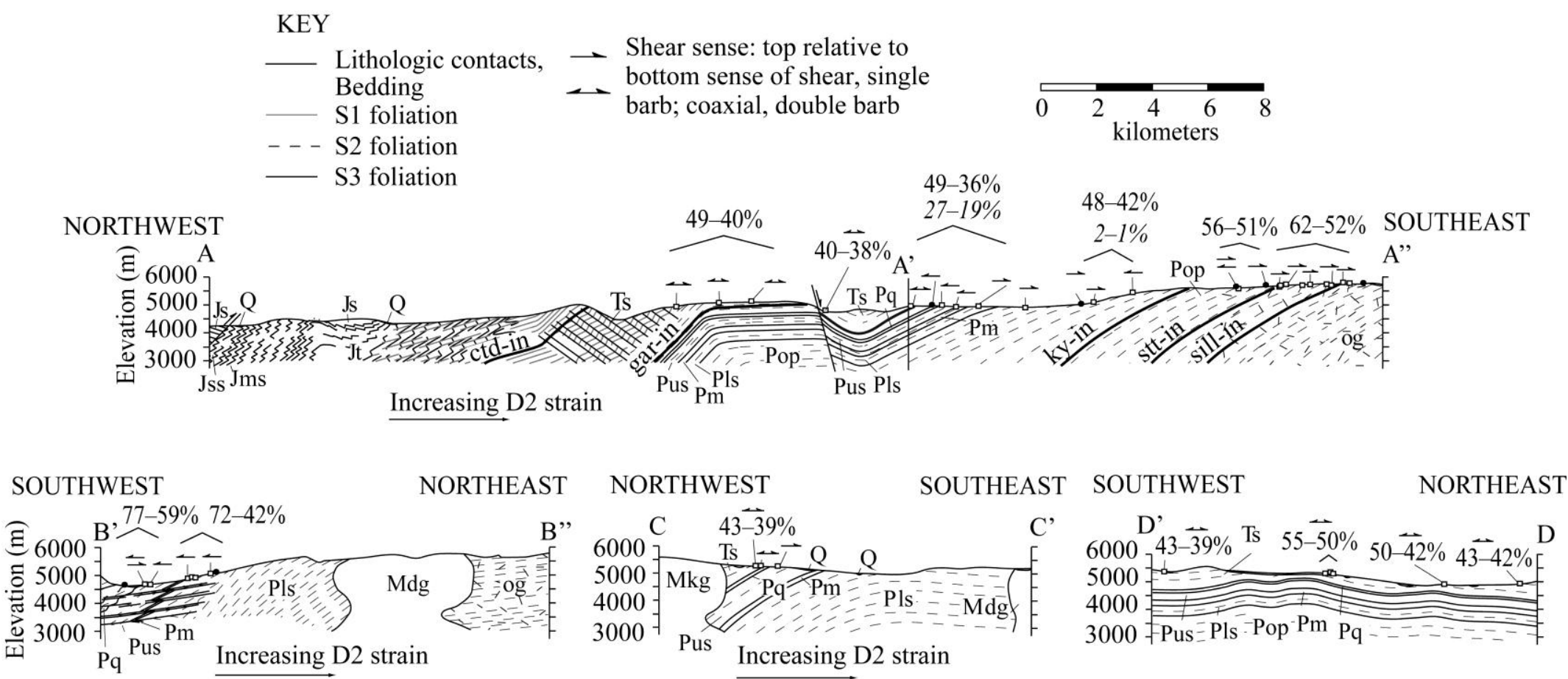

Figure 5. Cross sections across Mabja Dome. Sample locations, isograds, percent pure shear (italic corresponds to quartzite), and shear sense arrows are included. Refer to Figure 4 for cross section locations and legend. Transects A-A'-A'" and B'-B', modified from Lee et al. (2004). 
fabrics is D2, a high-strain deformational event that is manifested at higher structural levels as an S2 crenulation cleavage developed at high angles to S1. Strain associated with D2 increases down structural section such that at structural levels below the garnetin isograd, bedding and the $\mathrm{S} 1$ foliation have been transposed parallel to a mylonitic $\mathrm{S} 2$ foliation. Associated with the high-strain S2 foliation is a north-south-stretching lineation, Ls2. The S2 mylonitic foliation is parallel to lithologic contacts and dips moderately northwest on the northwest flank of the dome and moderately southwest on the southwest flank of the dome defining the domal geometry (Lee et al., 2004). Subsequent to the formation of D2 fabrics, the S2 foliation was domed into a doubly plunging, north-south-elongate antiformal dome. The S2 mylonitic foliation dips moderately outward from the center of the dome on the north, west, and south flanks (Lee et al., 2004).

Microstructural textures indicate that peak metamorphism occurred after D1 deformation and prior to or during the D2 deformation (Lee et al., 2004).

Metasedimentary rocks preserve a Barrovian peak metamorphic event defined by a prograde sequence of mineral assemblages (chloritoid-, garnet-, kyanite-, staurolite-, and sillimanite-in isograds) that increase toward the center of the dome (Figs. 4 and 5). Based on mineral assemblages and quantitative thermobarometry, Lee et al. (2004) inferred temperatures and pressures of $\sim 475-530{ }^{\circ} \mathrm{C}$ and $\sim 150-450 \mathrm{MPa}$ for the chloritoid-zone and calculated temperatures that increase from $575 \pm 50{ }^{\circ} \mathrm{C}$ in the garnet-zone to $705 \pm$ $65{ }^{\circ} \mathrm{C}$ in the sillimanite-zone and pressures from garnet-, staurolite-, and sillimanite-zone rocks that are constant at $\sim 800 \mathrm{MPa}$, regardless of structural depth. Lee et al. (2004) 
estimated that the metamorphic rocks were vertically thinned by $\sim 50-10 \%$ based on the apparent gradient in pressure between the chloritoid-in isograd and garnet-zone rocks, which is greater than expected for the structural depth.

$\mathrm{U} / \mathrm{Pb}$ zircon geochronology and ${ }^{40} \mathrm{Ar} /{ }^{39} \mathrm{Ar}$ and apatite fission-track

thermochronology indicate that D2 vertical thinning and horizontal extensional deformation, migmatization, and peak metamorphism began at about $35 \mathrm{Ma}$, was ongoing at $23 \mathrm{Ma}$, and had ceased by $16 \mathrm{Ma}$, a duration of 12-19 m.y. (Lee et al., 2006; Lee and Whitehouse, 2007). In Mabja Dome, metamorphic isograds, the S2 foliation, and mica ${ }^{40} \mathrm{Ar} /{ }^{39} \mathrm{Ar}$ chrontours are domed, but low-temperature potassium feldspar ${ }^{40} \mathrm{Ar} /{ }^{39} \mathrm{Ar}$ and apatite fission track chrontours are not. Therefore, doming occurred at temperatures between $\sim 400{ }^{\circ} \mathrm{C}$ (estimated blocking temperature for muscovite) and $\sim 200{ }^{\circ} \mathrm{C}$ (estimated blocking temperature for the low-temperature steps in potassium feldspar) (Lee et al., 2004, 2006). 


\section{CHAPTER III}

\section{KINEMATICS, DEFORMATION TEMPERATURES, AND VORTICITY}

To characterize patterns of ductile deformation in the mid-crustal rocks of Mabja Dome microstructural analyses on forty samples and quartz lattice-preferred orientation (LPO) analyses on eleven samples were completed to document shear sense and deformation temperatures. In addition, vorticity analyses on thirty samples were completed to document the spatial and temporal distribution of pure vs. simple shear deformation. Samples were collected from the Triassic siliciclastic sequence (unit Ts), Paleozoic schist, quartzite, and orthogneiss units (units Pq, Pus, Pls, and Pop), and from the basal orthogneiss (unit og) that span the metamorphic isograds from the chloritoidzone to the sillimanite-zone (Figs. 4 and 5).

\section{Kinematics}

The asymmetric geometry of strain shadows on metamorphic porphyroblasts (Fig. 6A), inclusion trail patterns within metamorphic porphyroblasts (Fig. 6B), shear bands, mineral fish, and quartz grain-shape foliations (Fig. 6C) were used to determine the spatial distribution of top-north and top-south sense of shear. Electron backscatter

diffraction (EBSD) analysis was used to generate quartz LPO patterns. The asymmetry of the c-, a-, and m-axes patterns with respect to the foliation and lineation was also used to determine shear sense (Fig. 7A) (e.g., Lister and Hobbs, 1980; Law, 1990).

Microstructures such as $\sigma$ - and $\delta$-type strain shadows on chloritoid and iron oxide porphyroblasts, inclusion patterns within chloritoid and iron oxides porphyroblasts, and 

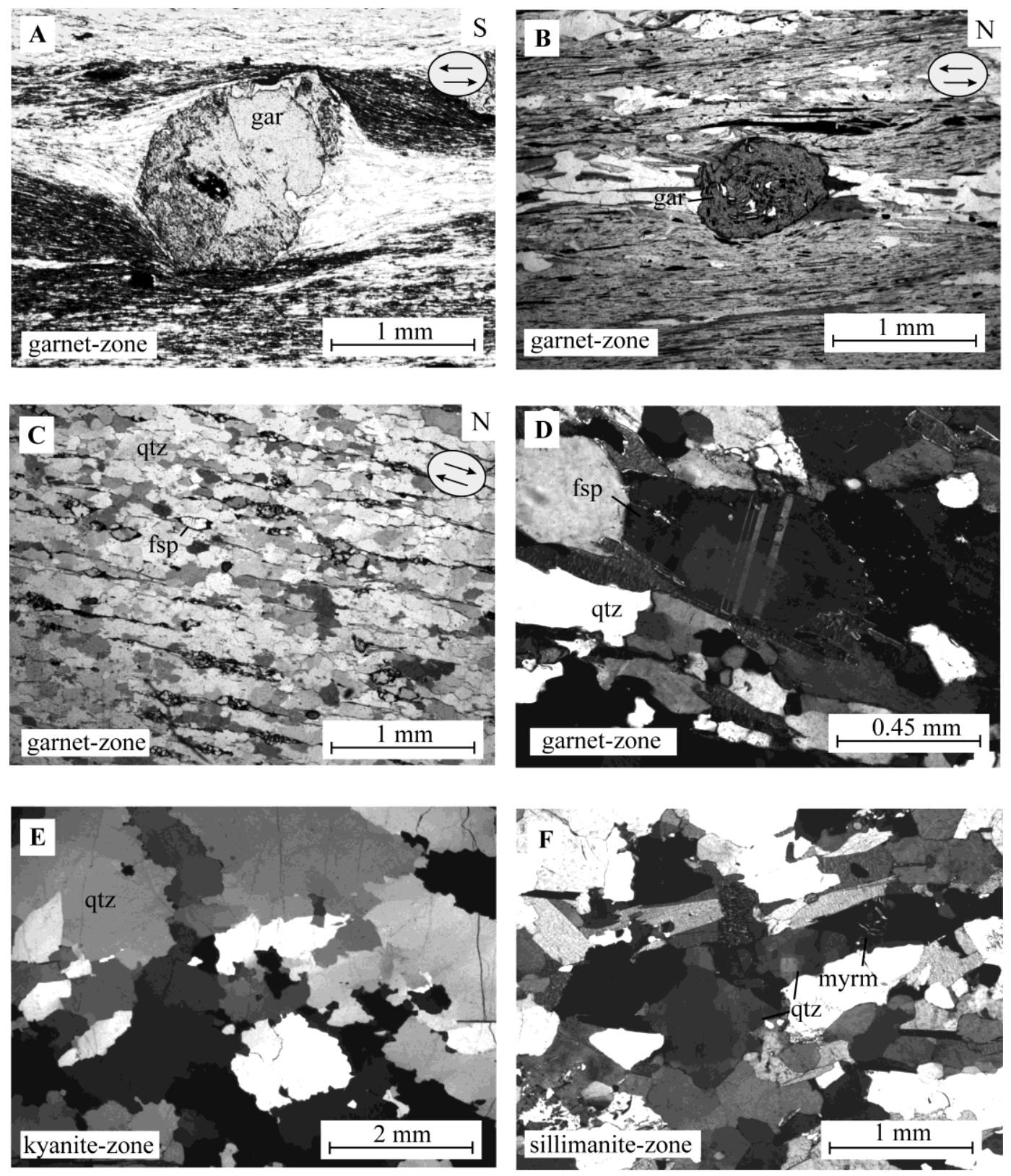

Figure 6. Photomicrographs of microstructures and quartz and feldspar deformation textures. (A) Strain shadow on garnet (gar) porphyroblast indicating top-north shear, plane light. (B) Anti-clockwise rotated inclusion trails in garnet indicating top-south shear, plane light. (C) Oblique quartz (qtz) grain-shape foliation indicating top-north shear; cross polars; fsp, feldspar. (D) Undulatory extinction in feldspar develops at $>450$ ${ }^{\circ} \mathrm{C}$, cross polars. (E) Grain boundary migration texture in recrystallized quartz indicates temperatures in excess of $500{ }^{\circ} \mathrm{C}$; cross polars. (F) Myrmekite (myrm) suggests temperatures $>600{ }^{\circ} \mathrm{C}$ and checkerboard extinction in quartz develops at $>700{ }^{\circ} \mathrm{C}$, cross polars. 

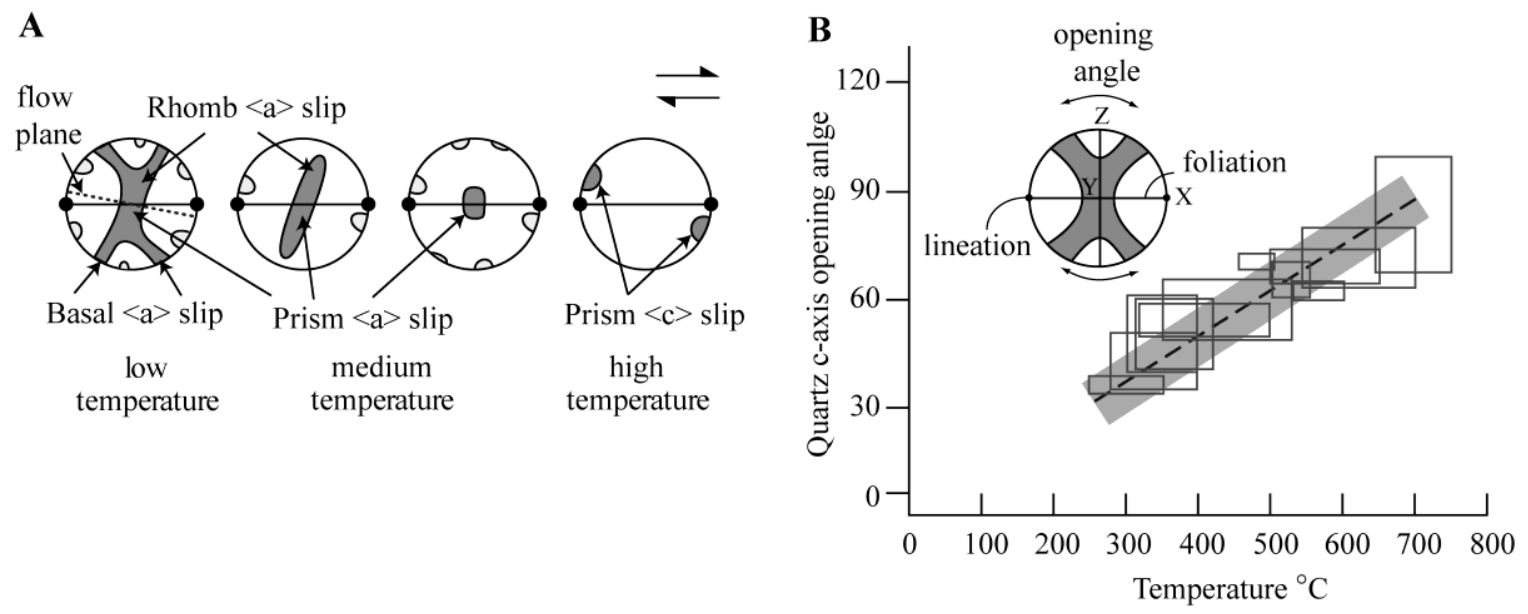

Figure 7. Quartz lattice-preferred orientation (LPO) patterns and associated temperature indicators. (A) Simplified stereonet plot showing the geometry of quartz LPO patterns and active slip systems with increasing deformation temperatures. C-axes are shown in dark grey and a-axes in light grey. Modified from Passchier and Trouw (2005). (B) Correlation of the c-axis opening angle to deformation temperature. The dashed line is the best fit line with $\pm 50^{\circ} \mathrm{C}$ error shown as a grey rectangle. The $\mathrm{X}, \mathrm{Y}$, and $\mathrm{Z}$ axes are shown. Modified from Law et al. (2004).

C'- type shear bands show both top-north and top-south shear at the thin section scale within the chloritoid-bearing rocks (Figure 5; Table 1). Quartz LPO patterns are poorly developed within this zone, thus providing no kinematic information (Fig. 8). Top-south kinematic indicators make up about 48 to $69 \%$ of the shear sense indicators, suggesting that top-south shear may be somewhat dominant. Overprinting or cross-cutting of the topnorth and top-south shear microstructures was not observed, suggesting that shear in both directions occurred simultaneously.

Microstructural shear sense indicators within garnet-zone rocks include $\delta$-type strain shadows on chloritoid, garnet, and iron oxide porphyroblasts, rotated internal foliation within garnet porphyroblasts, quartz grain-shape foliation, mica fish, and C' type shear bands. These microstructures show both top-north and top-south shear within 
TABLE 1. SUMMARY OF SHEAR SENSE, VORTICITY, AND TEMPERATURE DATA

\begin{tabular}{|c|c|c|c|c|c|c|c|}
\hline Sample & $\begin{array}{l}\text { Rock } \\
\text { type }\end{array}$ & $\begin{array}{l}\text { Shear } \\
\text { sense }\end{array}$ & $\begin{array}{c}\text { Vorticity } \\
\left(W_{\mathrm{m}}\right)\end{array}$ & $\begin{array}{c}\% \text { Pure } \\
\text { shear }\end{array}$ & $\begin{array}{l}\text { Deformation } \\
\text { temperature } \\
\left({ }^{\circ} \mathrm{C}\right)\end{array}$ & $\begin{array}{l}\text { Metamorphic } \\
\text { temperature } \\
\left({ }^{\circ} \mathrm{C}\right)\end{array}$ & $\begin{array}{c}\text { Temperature } \\
\text { indicator }\end{array}$ \\
\hline \multicolumn{8}{|c|}{ A-A'-A' Transect } \\
\hline \multicolumn{8}{|c|}{$\begin{array}{l}\text { ctd-in } \\
\end{array}$} \\
\hline $\operatorname{MDP}_{25} \mathrm{a}^{\dagger}$ & sch & both & $0.80-0.82$ & $40-38$ & $\sim 450-550$ & - & mineral assemblage \\
\hline MDP25b ${ }^{\dagger}$ & sch & both & $0.72-0.79$ & $49-41$ & $\sim 450-550$ & - & mineral assemblage \\
\hline MDP27 & $\arg$ & both & $0.74-0.80$ & $45-40$ & $\sim 450-550$ & - & mineral assemblage \\
\hline MDP28 & $\arg$ & both & $0.75-0.78$ & $44-42$ & $\sim 450-550$ & - & mineral assemblage \\
\hline \multicolumn{8}{|l|}{ gar-in } \\
\hline MD25 & sch & both & $0.80-0.82$ & $40-38$ & $\sim 450-550$ & - & mineral assemblage \\
\hline MD27 & sch & both & $0.77-0.78$ & $43-42$ & $\sim 450-550$ & - & mineral assemblage \\
\hline MD28 ${ }^{\dagger}$ & qtz & $t-n^{+}$ & $0.90-0.94$ & $27-19$ & $417-459 \pm 50$ & - & opening angle \\
\hline MD32 & sch & $t-n$ & $0.72-0.75$ & $49-44$ & $\sim 450-550$ & - & mineral assemblage \\
\hline MD31a & sch & $t-n$ & $0.72-0.75$ & $49-44$ & - & $626 \pm 55$ & Lee et al., 2004 \\
\hline MD29 & sch & $\mathrm{t}-\mathrm{s}$ & - & - & - & $575 \pm 50$ & Lee et al., 2004 \\
\hline MDP37 & sch & $\mathrm{t}-\mathrm{s}$ & $0.77-0.84$ & $43-36$ & - & - & - \\
\hline MD34 ${ }^{\dagger}$ & orth & $\mathrm{t}-\mathrm{s}^{\ddagger}$ & - & - & $475 \pm 50$ & - & opening angle \\
\hline $\mathrm{MD}^{\circ} 6^{\dagger}$ & qtz & $t-s, t-s^{*}$ & $0.98-0.99$ & $2-1$ & $529 \pm 50$ & - & opening angle \\
\hline $\mathrm{MDP} 45^{\dagger}$ & orth & $t-s, t-s^{*}$ & $0.74-0.78$ & $45-42$ & - & - & - \\
\hline MD38 ${ }^{\dagger}$ & orth & $t-n$ & $0.73-0.75$ & $48-44$ & $630 \pm 50$ & - & opening angle \\
\hline \multicolumn{8}{|l|}{ ky-in } \\
\hline$\overline{\mathrm{MDP}} 52 \mathrm{a}^{\dagger}$ & qtz & $t-n^{*}$ & - & - & $551-616 \pm 50$ & - & opening angle \\
\hline MDP52d & sch & $\mathrm{t}-\mathrm{s}$ & $0.62-0.69$ & $56-51$ & - & - & - \\
\hline MD40 ${ }^{\dagger}$ & qtz & $\mathrm{t}-\mathrm{s}, \mathrm{t}-\mathrm{s}^{*}$ & - & - & - & - & - \\
\hline \multicolumn{8}{|l|}{$\underline{\text { stt-in }}$} \\
\hline$\overline{\mathrm{MD} 42}$ & sch & $\mathrm{t}-\mathrm{s}$ & - & - & - & $635 \pm 58$ & Lee et al., 2004 \\
\hline MD44 & sch & $\mathrm{t}-\mathrm{s}$ & $0.62-0.67$ & $56-53$ & - & - & - \\
\hline
\end{tabular}


TABLE 1. (continued)

\begin{tabular}{|c|c|c|c|c|c|c|c|}
\hline Sample & $\begin{array}{c}\text { Rock } \\
\text { type }\end{array}$ & $\begin{array}{l}\text { Shear } \\
\text { sense }\end{array}$ & $\begin{array}{c}\text { Vorticity } \\
\left(W_{\mathrm{m}}\right)\end{array}$ & $\begin{array}{l}\% \text { Pure } \\
\text { shear }\end{array}$ & $\begin{array}{c}\text { Deformation } \\
\text { temperature } \\
\left({ }^{\circ} \mathrm{C}\right)\end{array}$ & $\begin{array}{c}\text { Metamorphic } \\
\text { temperature } \\
\left({ }^{\circ} \mathrm{C}\right)\end{array}$ & $\begin{array}{l}\text { Temperature } \\
\text { indicator }\end{array}$ \\
\hline $\begin{array}{l}\text { MDP56a } \\
\text { sill-in }\end{array}$ & amph & $\mathrm{t}-\mathrm{s}$ & $0.55-0.68$ & $62-52$ & - & - & - \\
\hline$\overline{\mathrm{MD} 51 \mathrm{a}}$ & sch & & - & - & - & $\sim 675$ & Lee et al., 2004 \\
\hline MDP65 & sch & $\mathrm{t}-\mathrm{s}$ & $0.57-0.67$ & $60-53$ & $>600$ & - & mineral assemblage \\
\hline MD53 & sch & $\mathrm{t}-\mathrm{s}$ & - & - & $>600$ & $705 \pm 65$ & Lee et al., 2004 \\
\hline MD55 & sch & $\mathrm{t}-\mathrm{s}$ & $0.60-0.68$ & $58-52$ & $>600$ & - & mineral assemblage \\
\hline MD58 & orth & $\mathrm{t}-\mathrm{s}$ & $0.52-0.68$ & $63-52$ & - & - & - \\
\hline $\mathrm{MDP}^{\dagger} 8^{\dagger}$ & orth & & $0.52-0.6$ & $63-58$ & $\sim 700$ & - & quartz textures \\
\hline MDP69apa $^{\dagger}$ & orth & & - & - & $\sim 700$ & - & quartz textures \\
\hline \multicolumn{8}{|c|}{ B'-B', Transect } \\
\hline \multicolumn{8}{|c|}{ gar-in } \\
\hline MD73 & qtz & & - & - & $>450$ & - & feldspar textures \\
\hline MD74a & $\operatorname{sch}$ & $\mathrm{t}-\mathrm{s}$ & $0.43-0.51$ & $71-64$ & $\sim 450-550$ & - & mineral assemblage \\
\hline MD74b & $\operatorname{sch}$ & $t-n$ & - & - & $\sim 450-550$ & - & mineral assemblage \\
\hline MD75 & $\operatorname{sch}$ & $\mathrm{t}-\mathrm{s}$ & $0.33-0.58$ & $77-59$ & $\sim 450-550$ & - & mineral assemblage \\
\hline MD76 & sch & $\mathrm{t}-\mathrm{s}$ & $0.74-0.78$ & $45-42$ & $\sim 450-550$ & - & mineral assemblage \\
\hline MD77 & $\operatorname{sch}$ & & $0.42-0.50$ & $72-65$ & $>450$ & - & feldspar textures \\
\hline MD93 & pgn & & $0.55-0.60$ & $62-58$ & $\sim 450-550$ & - & mineral assemblage \\
\hline MD94 & sch & $\mathrm{t}-\mathrm{s}$ & $0.58-0.62$ & $59-56$ & $\sim 450-550$ & - & mineral assemblage \\
\hline MD78 & qtz & & - & - & $>450$ & - & feldspar textures \\
\hline \multicolumn{8}{|c|}{$\frac{\text { C-C' Transect }}{\text { gar-in }}$} \\
\hline $\mathrm{MD84}$ & sch & both & $0.77-0.81$ & $43-39$ & $\sim 450-550$ & - & mineral assemblage \\
\hline MD83 & sch & both & - & - & $\sim 450-550$ & - & mineral assemblage \\
\hline MD82 & $\mathrm{sch}$ & both & - & - & $\sim 450-550$ & - & mineral assemblage \\
\hline
\end{tabular}


TABLE 1. (continued)

\begin{tabular}{|c|c|c|c|c|c|c|c|}
\hline Sample & $\begin{array}{l}\text { Rock } \\
\text { type }\end{array}$ & $\begin{array}{l}\text { Shear } \\
\text { sense }\end{array}$ & $\begin{array}{l}\text { Vorticity } \\
\left(W_{\mathrm{m}}\right)\end{array}$ & $\begin{array}{l}\% \text { Pure } \\
\text { shear }\end{array}$ & $\begin{array}{c}\text { Deformation } \\
\text { temperature } \\
\left({ }^{\circ} \mathrm{C}\right)\end{array}$ & $\begin{array}{l}\text { Metamorphic } \\
\text { temperature } \\
\left({ }^{\circ} \mathrm{C}\right)\end{array}$ & $\begin{array}{l}\text { Temperature } \\
\text { indicator }\end{array}$ \\
\hline \multicolumn{8}{|c|}{$\underline{\text { Transect D-D' }}$} \\
\hline \multicolumn{8}{|c|}{$\overline{\text { gar-in }}$} \\
\hline MD110 & $\operatorname{sch}$ & both & $0.71-0.78$ & $50-42$ & $\sim 450-550$ & - & mineral assemblage \\
\hline MD111 & sch & both & - & - & $\sim 450-550$ & - & mineral assemblage \\
\hline MD112 & sch & both & $0.69-0.71$ & $51-50$ & $\sim 450-550$ & - & mineral assemblage \\
\hline MD113 & sch & both & $0.63-0.70$ & $55-50$ & $\sim 450-550$ & - & mineral assemblage \\
\hline \multicolumn{8}{|c|}{$\begin{array}{l}\text { Notes: Abbreviations: amph, amphibolite; arg, argillite; orth, orthogneiss; pgn, paragneiss; qtz, quartzite; sch, schist } \\
\text { t-s, top-south; t-n, top-north. Samples are in order of increasing structural depth, except transect D-D’ where } \\
\text { all samples are from the same structural level. } \\
+ \text { sample analyzed with EBSD } \\
{ }^{\ddagger} \text { shear sense determined from EBSD-generated quartz LPO data }\end{array}$} \\
\hline
\end{tabular}




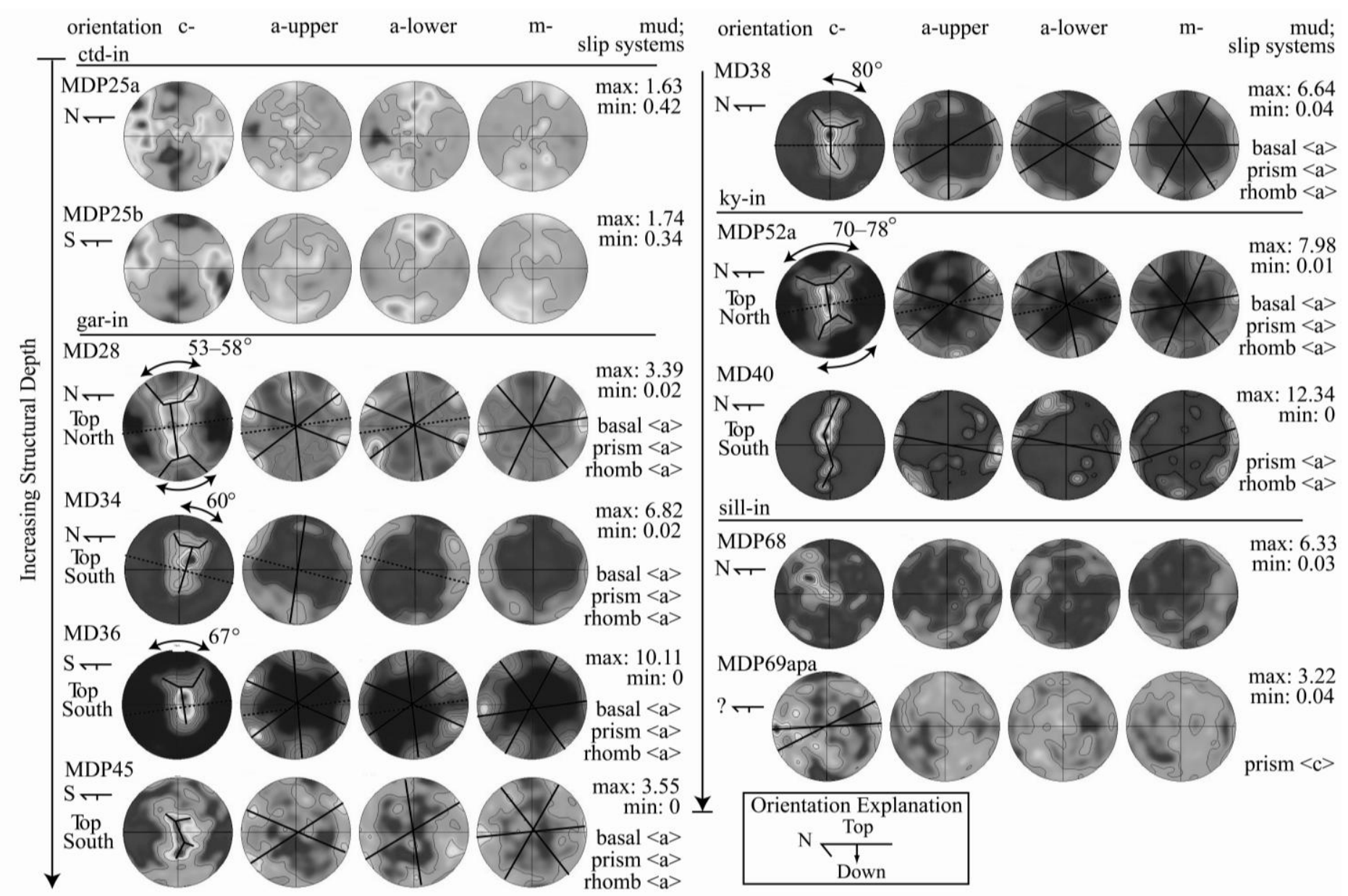

Figure 8. EBSD-generated oriented quartz LPO patterns from the A-A'-A"' transect. Upper hemisphere c-, upper and lower hemisphere a-, and upper hemisphere m-axes stereonet plots shown. Contouring is based on the mean uniform density (mud). Black lines are interpreted pattern skeletons. Dotted lines represent the flow plane. Metamorphic isograds, opening angle, and shear sense included. Min, minimum; max; maximum. 
the unit Ts which switches to top-north shear then flips to dominantly top-south shear with increasing structural depth (Fig. 5; Table 1). All quartz LPOs within the garnet-zone show c-axis girdles that along with the a- and m-axes are asymmetric to the foliation indicating top-north noncoaxial shear switching to top-south noncoaxial shear with structural depth, with the exception of sample MD38 which shows no c-axis asymmetry relative to the foliation (Fig. 8).

In kyanite-zone and deeper rocks, microstructures such as $\delta$-type strain shadows on garnet porphyroblasts, inclusion patterns within garnet porphyroblasts, quartz grainshape foliation, and C'-type shear bands show solely top-south shear. Quartz LPOs from sample MDP52a exhibit a c-axis girdle that, along with the a- and m-axes, are asymmetric to the foliation showing top-north shear sense. Sample MD40 exhibits a caxis single-girdle and a- and $\mathrm{m}$ - axes that are asymmetric to foliation showing top-south shear sense. While sample MDP69apa has an asymmetry, it is not oriented so no kinematic information was obtained (Fig. 8).

\section{Deformation Temperatures}

Several techniques were used to estimate deformation temperatures during the development of the kinematic and quartz LPO fabrics described above. A temperature range was estimated based upon mineral assemblages preserved within the strain shadows on rotated porphyroblasts, quartz and feldspar textures, and quartz slip systems (e.g., Mainprice et al., 1986; Jessell, 1987; Tullis and Yund, 1992; Fitz Gerald and Stünitz, 1993; Lloyd and Freeman, 1994; Hirth et al., 2001; Stipp et al., 2002a, b). Deformation temperature was also estimated based on the opening angle of quartz c-axis 
LPO patterns (Kruhl, 1998; Law et al., 2004), where the opening angle is defined as the angle between the girdles measured in the plane perpendicular to foliation and parallel to lineation (Fig. 7B) (Kruhl, 1998). Experimental (e.g., Tullis et al., 1973) and numerical simulation studies (e.g., Lister et al., 1978; Lister and Hobbs, 1980; Lister and Dornsiepen, 1982; Wenk et al., 1989) indicate that the opening angle of quartz c-axis LPO patterns increases as a function of increasing deformation temperature. Taking into account the range in strain rates in naturally deformed rocks, Kruhl (1998) estimated a deformation temperature uncertainty of $\pm 50{ }^{\circ} \mathrm{C}$ for the opening angle thermometer.

The strain shadows of chloritoid, iron oxides, and tourmaline porphyroblasts in the chloritoid-zone contain quartz + biotite + muscovite \pm chlorite. This mineral assemblage suggests deformation temperatures of $\sim 450-550{ }^{\circ} \mathrm{C}$ (Fig. 9; Table 1) (Spear and Menard, 1989). Quartz in the chloritoid-zone exhibits undulatory extinction and brittle fracturing is absent indicating temperatures of at least $\sim 350{ }^{\circ} \mathrm{C}$ (Stipp et al., 2002a; Passchier and Trouw, 2005). Quartz LPOs from the chloritoid-zone are poorly developed (Fig. 8) which may indicate low temperatures (200-400 $\left.{ }^{\circ} \mathrm{C}\right)$ (Mainprice et al., 1986). Quartz + biotite + muscovite \pm chlorite are present in the strain shadows around chloritoid, garnet, iron oxide, tourmaline, and in one sample biotite, porphyroblasts in garnet-zone rocks suggesting deformation temperatures of $\sim 450-550{ }^{\circ} \mathrm{C}$ (Fig. 9; Table 1) (Spear and Menard, 1989). Quartz exhibits a weak grain-shape foliation (Fig. 6C), deformation lamellae, undulose extinction, and regime two recrystallization (Hirth and Tullis, 1992) with subgrain rotation combined with weak grain boundary migration at structural depth indicating temperatures of at least $\sim 500{ }^{\circ} \mathrm{C}$ (Stipp et al., 2002a, b; 


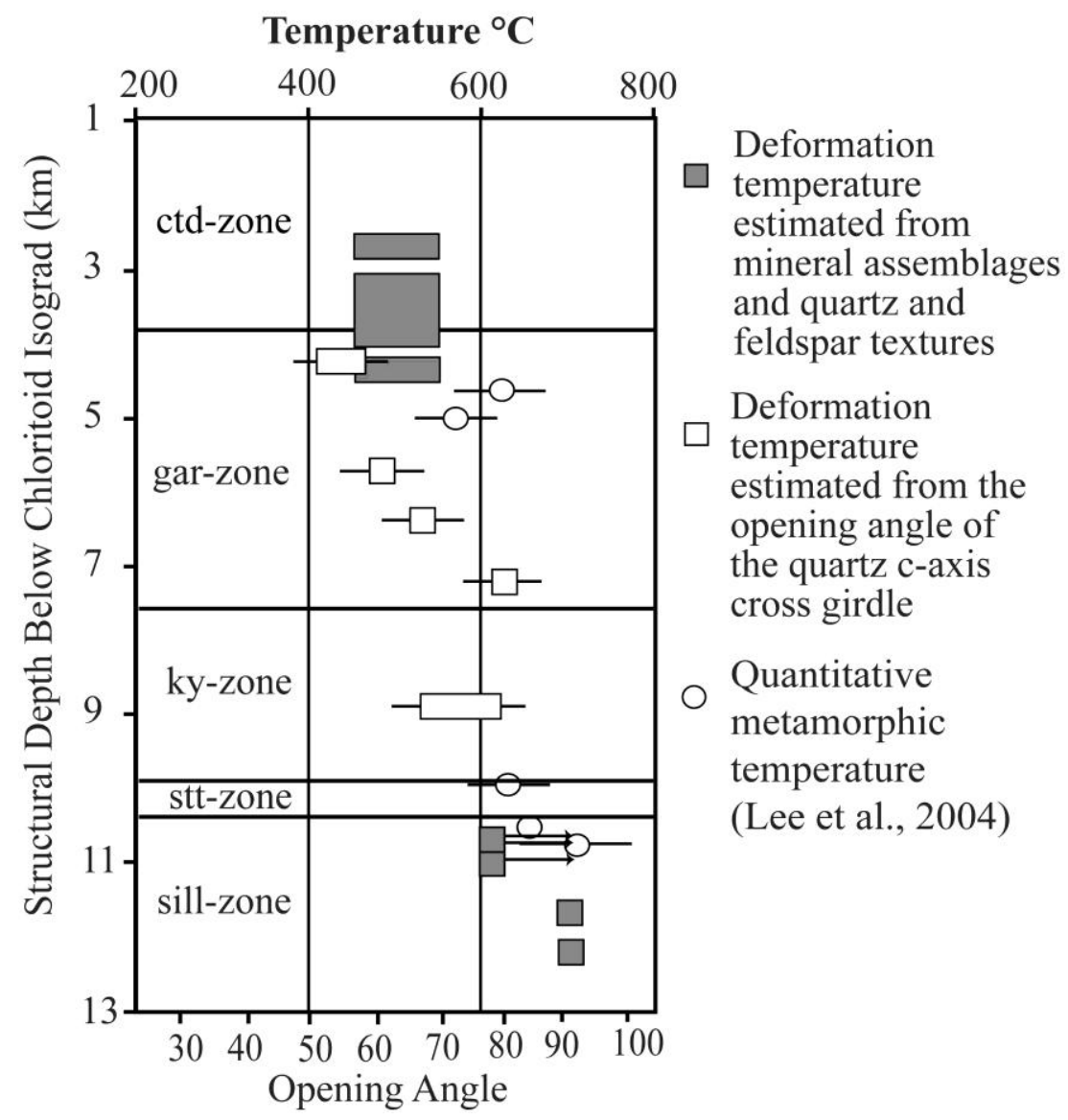

Figure 9. Estimated deformation temperatures with error bars for schists, orthogneisses, and quartzites. Arrows indicate that temperatures are a minimum and could be greater. Estimates based on mineral assemblages, quartz and feldspar textures, and quartz c-axis fabrics as a function of structural depth below the chloritoid-in isograd. Quantitative metamorphic temperatures from Lee et al. (2004) and opening angles of quartz fabrics included. Ctd, chloritoid; gar, garnet; ky, kyanite; stt, staurolite; sill, sillimanite.

Passchier and Trouw, 2005). Feldspar exhibits undulatory extinction suggesting temperatures in excess of $450{ }^{\circ} \mathrm{C}$ (Passchier and Trouw, 2005). Quartz c-axis LPO patterns show a transition with structural depth from basal $<a>$, rhomb $<a>$, and prism $<\mathrm{a}>$ slip to rhomb $<\mathrm{a}>$ and prism $<\mathrm{a}>$ slip indicating a transition from low $\left(400-500{ }^{\circ} \mathrm{C}\right)$ to moderate deformation temperatures $\left(<650{ }^{\circ} \mathrm{C}\right)$ (Figs. 7 and 8) (Mainprice et al., 1986). In addition, the opening angles of quartz LPO cross-girdles within garnet-zone rocks 
suggest deformation temperatures that increase from $417 \pm 50{ }^{\circ} \mathrm{C}$ to $630 \pm 50{ }^{\circ} \mathrm{C}$ (Figs. 8 and 9; Table 1).

Mineral assemblages within strain shadows around garnet porphyroblasts within the kyanite-zone and deeper rocks contain quartz + biotite + muscovite and \pm sillimanite within the sillimanite-zone suggesting deformation temperatures in excess of $600{ }^{\circ} \mathrm{C}$ at the deepest structural levels. Quartz exhibits regime three recrystallization (Hirth and Tullis, 1992) which is characterized by subgrain rotation and grain boundary migration. Regime three recrystallization transitions to dominantly grain boundary migration (Fig. 6E) with structural depth indicating an increase in temperatures from $\sim 500{ }^{\circ} \mathrm{C}$ to $\sim 650{ }^{\circ} \mathrm{C}$ (Stipp et al., 2002a). Weakly developed checkerboard extinction is present at the deepest structural levels indicating temperatures in excess of $700{ }^{\circ} \mathrm{C}$ (Fig. 6F) (Stipp et al., 2002a; Passchier and Trouw, 2005). Feldspar exhibits myrmekite at the deepest structural levels indicating temperatures of $>700{ }^{\circ} \mathrm{C}$ (Fig. 6F). Quartz c-axis LPO patterns within the kyanite-zone and deeper rocks show a transition with structural depth from basal <a>, rhomb $<\mathrm{a}>$ and prism $<\mathrm{a}>$ slip to a poorly developed prism $<\mathrm{c}>$ slip at the deepest structural levels indicating moderate $\left(400-500{ }^{\circ} \mathrm{C}\right)$ to high $\left(500-700{ }^{\circ} \mathrm{C}\right)$ temperatures. Sample MDP68 likely shows rhomb <a> and prism <a> slip but it is aligned off-center (Fig. 8). The opening angle of the LPO from sample MDP52a, collected from the middle of the kyanite-zone, suggests a deformation temperature of $515-616 \pm 50{ }^{\circ} \mathrm{C}$ (Fig. 8).

\section{Vorticity}

To characterize the style of flow recorded in the strongly deformed mid-crustal rocks of Mabja Dome, vorticity analyses to document the relative percentage of pure and 
simple shear during ductile deformation were completed. Characterizing vorticity is important because a large pure shear component indicates significant vertical thinning and horizontal extension, and an increase in strain and extrusion rates relative to simple shear. Kinematic vorticity number $\left(W_{\mathrm{k}}\right)$ measures the relative contributions of pure $\left(W_{\mathrm{k}}=\right.$ 0) and simple $\left(W_{\mathrm{k}}=1\right)$ shear during steady-state (instantaneous) deformation; pure and simple shear components are equal when $W_{\mathrm{k}}=0.71$ (Means et al., 1980; Law et al., 2004). However, the vorticity of flow varies both spatially and temporally in naturally deformed rocks (e.g., Fossen and Tikoff, 1997, 1998; Jiang, 1998). In such cases of nonsteady state deformation, flow vorticity is better characterized by the mean kinematic vorticity number $\left(W_{\mathrm{m}}\right)$. Vorticity analysis methods were applied to thin sections cut perpendicular to the foliation and parallel to lineation. Measurements were made either directly from the thin section or from photomicrographs of the thin section. From the photomicrographs, the best fitting ellipse was determined using the imaging software, ImageJ (Rasband, 2005). The rigid grain and grain-shape foliation techniques were used to measure vorticity recorded within a sample.

The rigid grain technique (Wallis et al., 1993), entails measuring the aspect ratio $(R)$ of a rigid porphyroblast such as garnet, chloritoid, and tourmaline and the acute angle ( $\theta$ ) between the clast long axis and the macroscopic foliation (Fig. 10) where:

$$
R=M_{\mathrm{x}} / M_{\mathrm{n}}
$$

$M_{\mathrm{x}}$ is the long axis and $M_{\mathrm{n}}$ is the short axis. Grains above a critical aspect ratio $\left(R_{\mathrm{c}}\right)$ will 


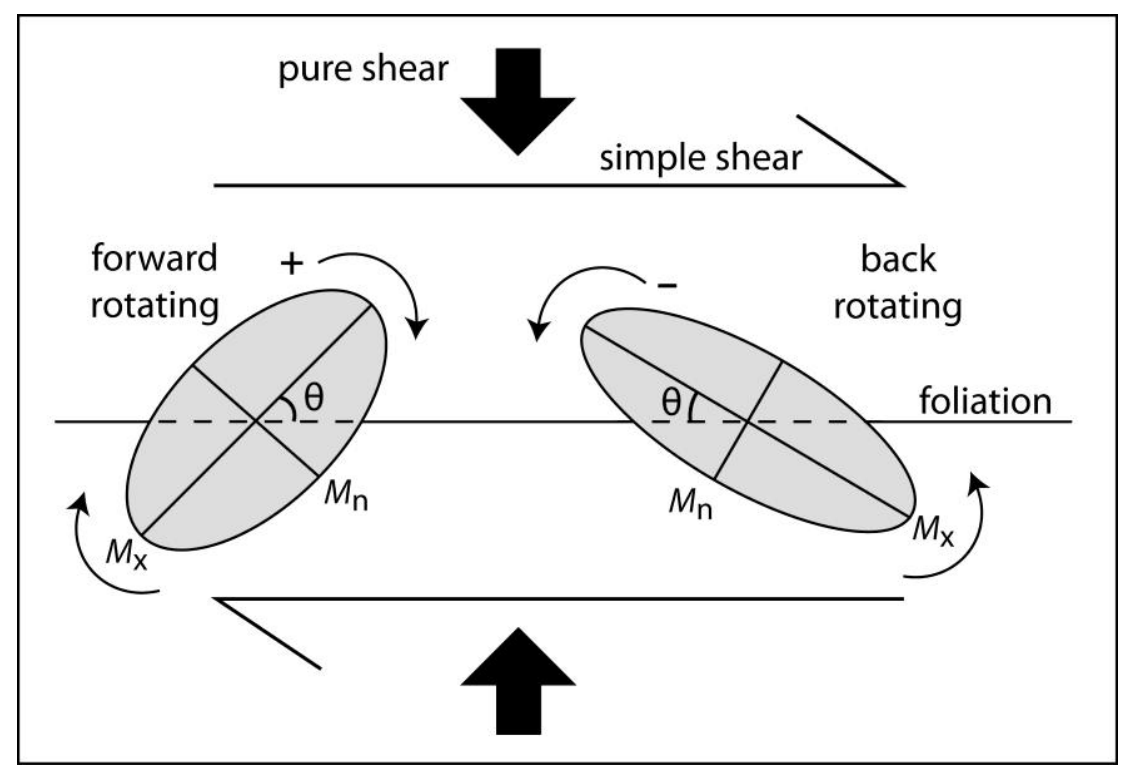

Figure 10. Rotation of elliptical porphyroblasts as a result of a combination of simple and pure shear. The $M_{\mathrm{x}}$ (long axis) is at a positive angle ( $\theta$ ) to the foliation during forward rotation and $M_{\mathrm{x}}$ is at a negative angle to the foliation during back rotation. $M_{\mathrm{n}}$, short axis. Modified from Jessup et al., (2007).

rotate into a stable orientation, whereas grains below will rotate freely. From $R_{\mathrm{c}}$, vorticity can be calculated using the equation (Passchier, 1987):

$$
W_{\mathrm{m}}=\left(R_{\mathrm{c}}^{2}-1\right) /\left(R_{\mathrm{c}}^{2}+1\right)
$$

A direct approach is to plot the shape factor $\left(B^{*}\right)$ :

$$
B^{*}=\left(M_{\mathrm{x}}^{2}-M_{\mathrm{n}}{ }^{2}\right) /\left(M_{\mathrm{x}}^{2}+M_{\mathrm{n}}{ }^{2}\right)
$$

versus $\theta$ on a the rigid grain net (Fig. 11; Jessup et al., 2007). Similar to $R_{\mathrm{c}}$, the critical shape factor $\left(B^{*}{ }_{c}\right)$ separates grains which rotate freely versus those that reach a stable 

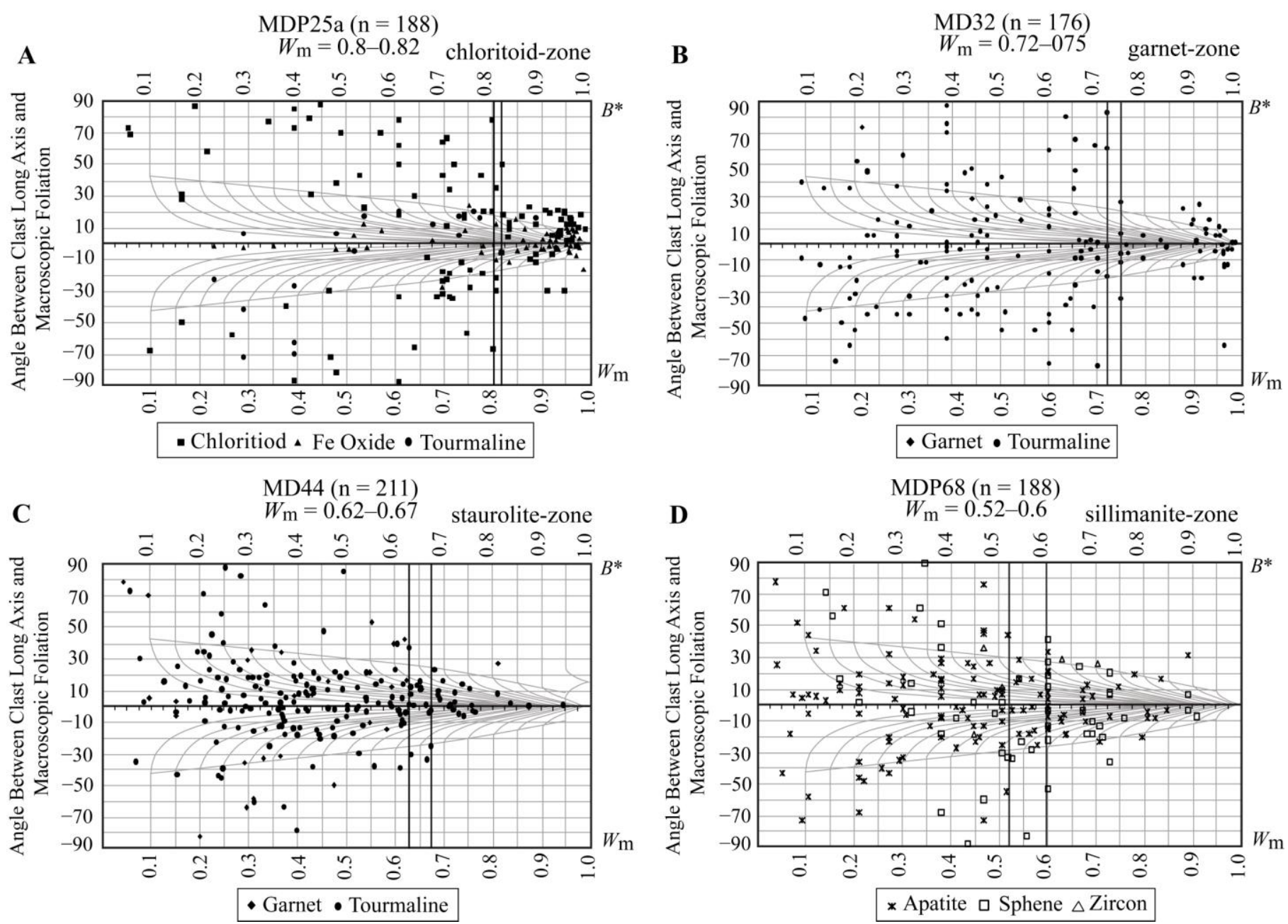

Figure 11. Representative rigid grain net plots of porphyroblast aspect ratios vs. the angle between the porphyroblast long axis and macroscopic foliation. Examples from the chloritoid-zone (A), garnet-zone (B), staurolite-zone (C), and sillimanitezone rocks (D). Black lines represent both $B^{*}{ }_{\mathrm{c}}$ (the critical shape factor) and the estimated $W_{\mathrm{m}}$ and $\mathrm{n}=$ the number of data points. Additional rigid grain net plots available in the Appendix. Digital data is available in Plate 1. 
orientation. $B^{*}$ and $W_{\mathrm{m}}$ are scaled one to one, thus $W_{\mathrm{m}}$ can be determined directly from $B^{*}$.

To successfully apply the rigid grain technique, the following criteria must be met: (1) the porphyroblasts predate the dominant deformation fabric; (2) the porphyroblasts are internally undeformed; and (3) there is no mechanical interaction between adjacent blasts or the matrix. Uncertainties in vorticity values estimated using this technique can be attributed to: (1) nonsymmetric porphyroblasts that may be between two stable orientations; (2) changes in the aspect ratio $(R)$ during or after deformation due to recrystallization; (3) high-aspect ratio rigid grains in low strain rocks may not have rotated into their stable orientations leading to an overestimate in the simple shear component; and (4) the fracturing of rigid grains with high-aspect ratios (Jessup et al., 2007). In order to limit these potential uncertainties, rigid grains that were used to estimate vorticity showed little to no sign of recrystallization and rigid grains with highaspect ratios were not fractured.

The grain-shape foliation technique (Wallis, 1995), entails measuring the acute angle $(\theta)$ between the long axis of oblique quartz grains and the flow plane. The flow plane can be defined as the perpendicular to the central c-axis girdle (Figs. 7A and 8) (Law et al., 1990; Wallis, 1995). During deformation, newly recrystallized grains (e.g., quartz) are stretched parallel to the extending instantaneous stretching axis (ISA). The maximum angle between the oblique grain-shape fabric and flow plane provides an approximate orientation of the ISA (Wallis, 1995). The orientation of the ISA is related to $W_{\mathrm{m}}$ by the equation (Wallis, 1995): 


$$
W_{\mathrm{m}}=\sin 2 \theta
$$

In order to accurately define the ISA, which reaches a maximum angle at $45^{\circ}, \theta$ for $\sim 100$ quartz grains per sample were measured. The maximum angle or the ISA was visually defined as a range in angles related to the vorticity where the best fit probability curve on the grain-shape foliation plot dramatically declines and begins to level out (Fig. 12). The probability curve represents the most likely (or best fit) distribution of angles based on the angles measured. The grain-shape foliation technique requires well developed LPOs and well developed grain-shape preferred orientations in order to accurately define both the flow plane and the ISA (Wallis, 1995; Xypolias and Koukouvelas, 2001).

Mean vorticity estimates for schists and orthogneisses from two transects approximately parallel to structural depth, A-A'-A" and C-C', and one perpendicular to structural depth, D-D', (Fig. 4) range from 0.72-0.82 (49-38\% pure shear) within chloritoid-zone rocks to $0.63-0.84$ (55-36\% pure shear) within garnet-zone rocks (Fig. 13; Table 1). Schists and orthogneisses in garnet-zone rocks to the south along a transect parallel to structural depth, B'-B', (Fig. 4) record $W_{\mathrm{m}}$ that ranges from $0.33-0.62$, indicating a significantly higher (77-56\%) component of pure shear. The exception is sample MD76 which yields a $W_{\mathrm{m}}$ of $0.74-0.78$ (45-42\% pure shear) (Fig. 13; Table 1). Schist and orthogneiss mean vorticity decreases from $0.62-0.69$ (56-51\% pure shear) within the kyanite-zone rocks to $0.52-0.68$ (63-52\% pure shear) within the stauroliteand sillimanite-zone rocks (Fig. 13, Table 1). Quartzites yield significantly higher mean 

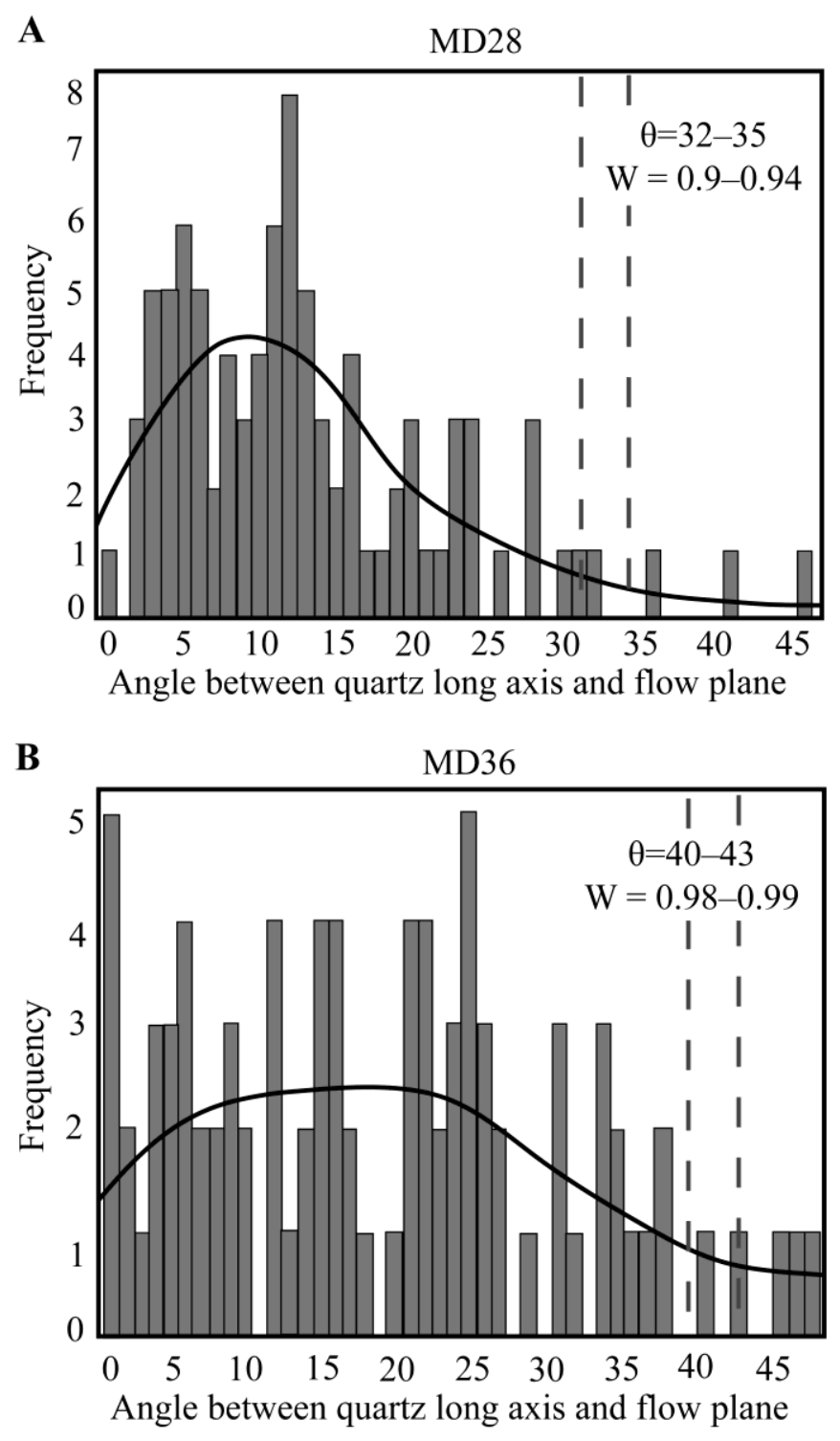

Figure 12. Grain-shape foliation plots of the angle $(\theta)$ between the quartz long axis and flow plane vs. frequency. Samples MD28 (A) and MD36 (B) are from the garnet-zone. Solid line shows the best fit probability curve and dashed lines show the range in angles of the instantaneous stretching axis (ISA). 


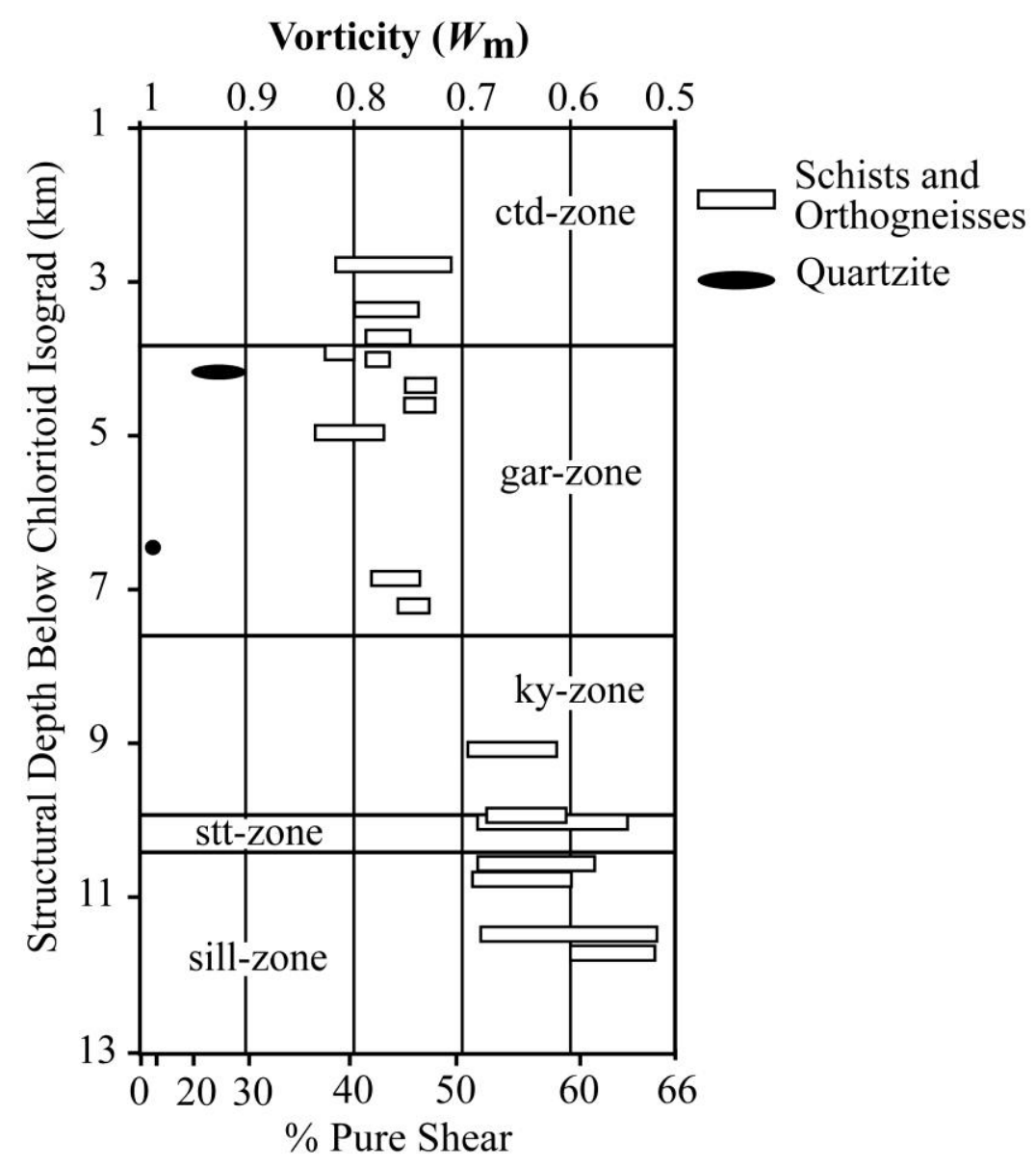

Figure 13. Vorticity and percent pure shear for schists, orthogneisses, and quartzites. Plotted as a function of structural depth below the chloritoid-in isograd along transect, AA'-A'” (see Figure 4).

vorticity values of 0.90-0.99 indicating deformation characterized by subsimple shear (27-1\% pure shear) (Figs. 12 and 13; Table 1). Percent pure shear values recorded in schists and orthogneisses across a portion of Mabja Dome clearly shows an increase in the pure shear component with structural depth and toward the south (Fig. 14). 


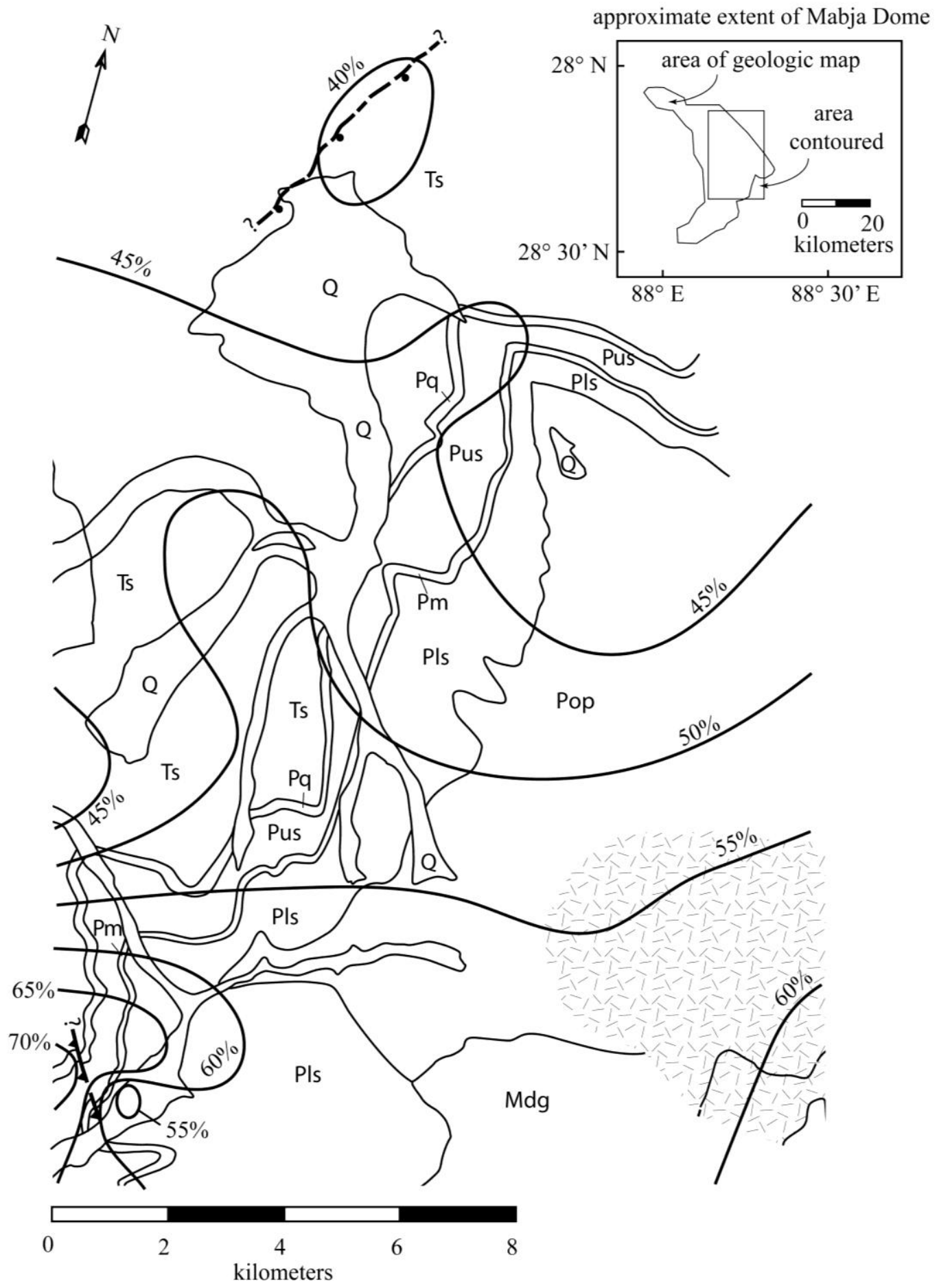

Figure 14. Contour map of the average percent pure shear estimated for schists and orthogneisses across a portion of Mabja Dome. Contours interpolated from sample locations and $W_{\mathrm{m}}$ estimates using ArcGIS (ESRI, 2005). Contour interval is 5\%. See Figures 4 and 5 for legend and sample locations. 


\section{CHAPTER IV}

\section{DISCUSSION}

Microstructural kinematic indicators and quartz LPOs of the dominant D2 vertical thinning and horizontal stretching fabric show that shear sense varies across Mabja Dome from both top-south and top-north shear within chloritoid-zone rocks, dominantly topsouth shear within garnet and kyanite-zone rocks, and solely top-south shear within the staurolite-zone and deeper rocks (Fig. 5; Table 1). In contrast, kinematics of flow associated with the D2 ductile extensional deformation event was dominantly top-north shear in Kangmar, Kampa, and Malashan gneiss domes (Chen et al., 1990; Lee et al., 2000; Aoya et al., 2005, 2006; Quigley et al., 2008) (Fig. 1).

Deformation temperatures associated with sense of shear fabrics and vorticity values increase with structural depth from $\sim 450{ }^{\circ} \mathrm{C}$ within chloritoid-zone rocks, to $\sim 600$ ${ }^{\circ} \mathrm{C}$ within garnet-zone rocks, and to $\sim 700{ }^{\circ} \mathrm{C}$ at the deepest structural levels within sillimanite-zone rocks (Fig. 9; Table 1). Estimated deformation temperatures overlap with quantitative metamorphic petrology temperature estimates (Figs. 9 and 15) (Lee et al., 2004) and define a $\sim 34^{\circ} \mathrm{C} / \mathrm{km}$ deformation temperature gradient. These relations show that kinematic fabrics and vorticity values were recorded in these rocks at peak metamorphic conditions, consistent with textural relations that show peak metamorphism was pre- to syn-D2 deformation (Lee et al, 2004).

The schists and orthogneisses record general shear deformation $\left(W_{\mathrm{m}}=0.33-0.82\right.$, 77-38\% pure shear) with an increasing component of pure shear with structural depth as a result of an increase in lithostatic load with depth. Quartzites, the mechanically weakest 


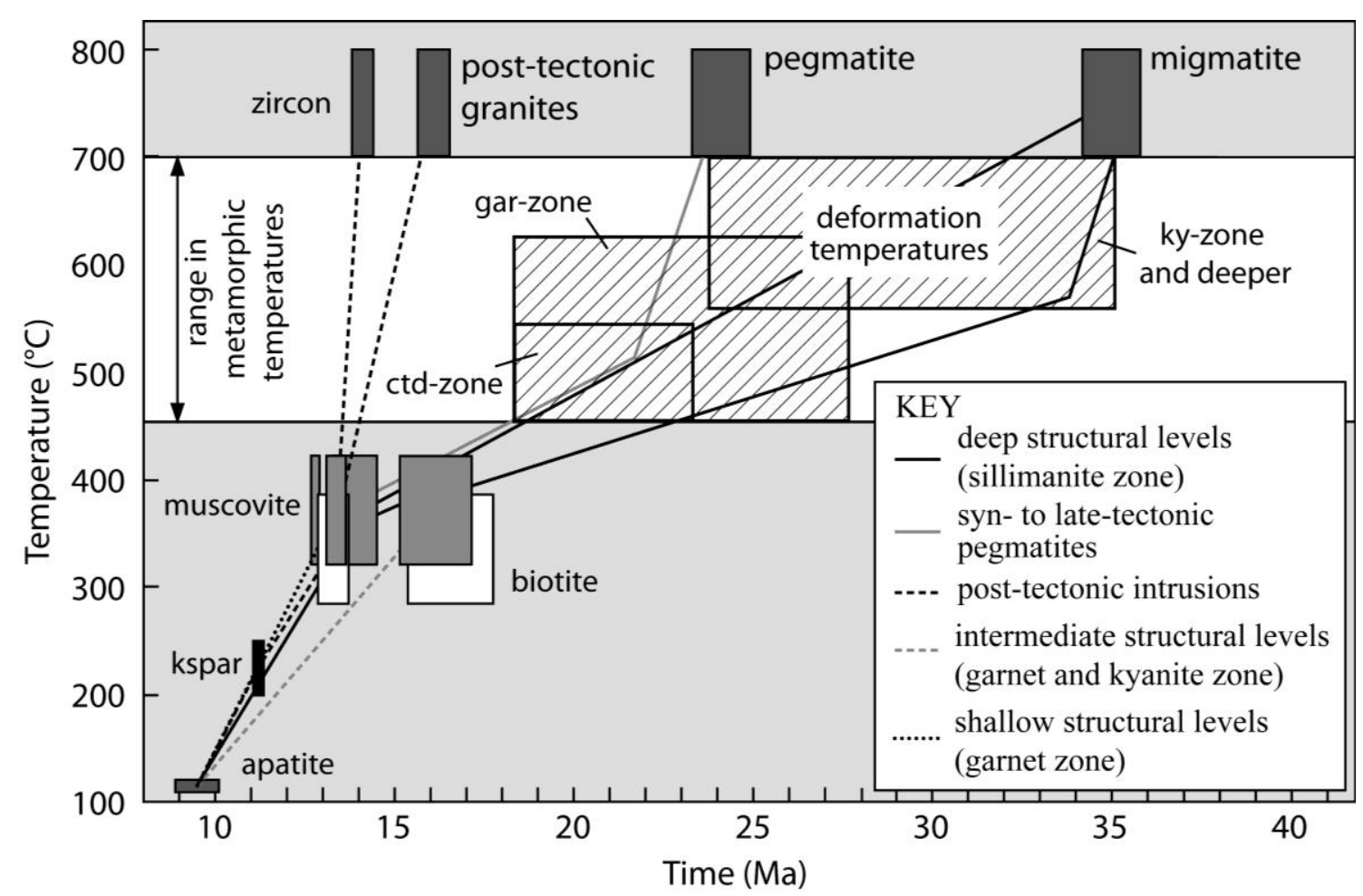

Figure 15. Temperature-time plot showing cooling histories for deformed migmatites and pegmatites and undeformed granites in Mabja Dome. The range in metamorphic temperatures from Lee et al. (2004) are indicated and overlap with deformation temperatures (see Figure 9 and Table 1). Modified from Lee et al., (2006).

layers, record simple shear (Fig. 13; Table 1). This new kinematic, vorticity, and deformation temperature data, combined with quantitative metamorphic temperature estimates (Lee et al., 2004) show that migmatization, metamorphism, and D2 deformation were synchronous. U/Pb zircon and ${ }^{40} \mathrm{Ar} /{ }^{39} \mathrm{Ar}$ mica ages (Lee et al., 2006; Lee and Whitehouse, 2007) indicate that D2 shear and decreasing vorticity values with depth initiated at $35.0 \pm 0.8 \mathrm{Ma}$ was ongoing at $23.1 \pm 0.8 \mathrm{Ma}$, and had ceased by $16.2 \pm$ 0.4 Ma (Fig. 15).

In the coupled thermal-mechanical model, melt-weakened, low viscosity middle crust flows southward (Fig. 2A) (Beaumont et al., 2004, 2006). In this model, Poiseuille 
flow, characterized by the highest velocities at the center of the channel and top-north simple shear at the top of the channel grading through general shear to pure shear at the center of the channel which in turn grades through general shear to top-south simple shear at the base of the channel, dominates within the channel; Couette flow, characterized by top-south shear, dominates beneath the channel (Fig. 3). In the geometric and kinematic (non-thermal) channel flow/extrusion models, shear sense should grade from top-north simple shear or general shear at the top of the channel through general shear to pure shear at the center of the channel which in turn grades through general shear to top-south simple shear or general shear at the base of the channel (Figs. 2B and C) (e.g., Vannay and Grasemann, 2001; Grujic et al., 2002; Godin et al., 2006; Grujic, 2006). These patterns of ductile flow in middle crustal rocks exposed in Mabja Dome, mixed top-north and top-south shear and a 40-50\% pure shear component at the top grading into solely top-south shear and $\sim 50-65 \%$ pure shear component at the bottom, are substantially different compared those predicted by the coupled thermal-mechanical and geometric and kinematic (non-thermal) channel flow/extrusion models (Fig. 2).

Reverse flow within the channel may explain the observed mixed top-north and top-south shear grading into solely top-S shear with structural depth (Fig. 16). Reverse flow can be driven by variations in flow velocity as a result of heterogeneity in viscosity and pressure differences along the length of the channel as a result of spatially varying channel thickness (Mancktelow, 1995; Grujic, 2006). In Mabja Dome rocks, the former may explain the observed top-north and top-south in chloritoid-bearing rocks. These 


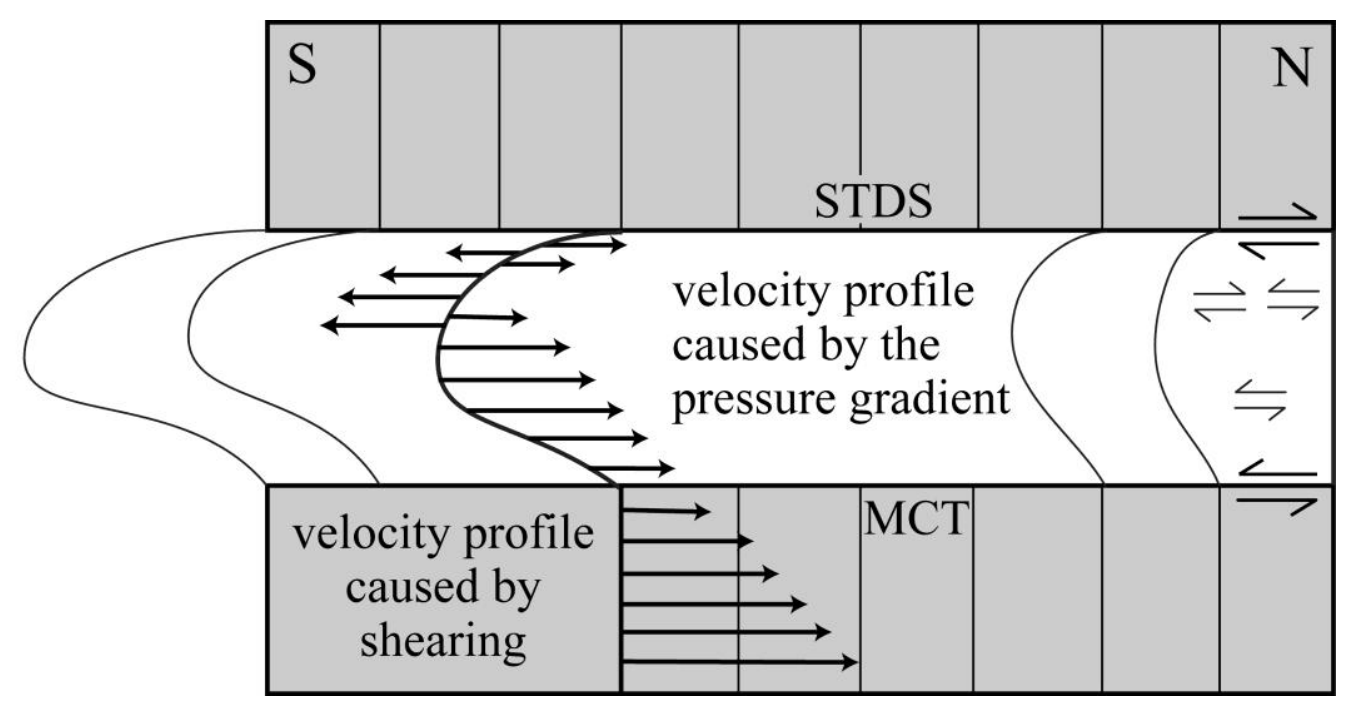

Figure 16. Interpretation of the velocity profile within the mid-crustal rocks now exposed in the core of Mabja Dome. The velocity profile is the result of a combination of Poiseuille and Couette flow, spatial variations in flow direction as a result of rheological differences, and a decrease in channel width. Arrow pairs indicate shear sense.

rocks are composed, in large part, of graphite-bearing schists. Graphite is rheologically weak causing localization of ductile strain during deformation. However, studies on graphitic schists in the Alps show that if fluids are present during deformation, the graphite can become brittle at conditions where it would generally be ductile (Selverstone, 2005). Heterogeneous fluid content throughout the graphitic schists will generate zones of varying viscosity due to strengthening of the graphite producing zones of opposing shear sense at the microstructural scale, such as those recorded in the chloritoid-bearing schists. Moreover, the dominant top-south shear at deeper structural levels may be the consequence of a significantly greater component of Couette flow, due to underthrusting beneath the MCT, compared to Poiseuille flow. If one assumes a crust of uniform density and a parallel-sided channel, then four factors might influence the style of channel flow: (1) the pressure gradient along the channel; (2) viscosity within the 
channel; (3) thickness of the channel; and (4) the velocity of the bounding plates (Turcotte and Schubert, 2002). A decrease in pressure gradient, increase in viscosity within the channel, decrease in channel thickness, and/or increase in relative plate velocity will lead to an increase in Couette flow. This means that either the gravitational potential energy difference necessary to drive Poiseuille flow was not sufficiently large or erosion on the southern front of the Himalaya had not developed or was weakly developed.

Vorticity and deformation temperature data from Mabja Dome differs somewhat from similar data from mid-crustal GHS rocks exposed in the Everest Massif region (Law et al., 2004; Jessup et al., 2006), 140 km southwest of Mabja Dome (Fig. 1). Here, vorticity studies showed that high-grade, structurally deep rocks at the top of the GHS record general shear (48-41\% pure shear) at close to peak metamorphic conditions whereas lower-grade, structurally higher rocks record subsimple shear (38-36\% pure shear) at somewhat lower temperatures (Law et al., 2004; Jessup et al., 2006). At the base of the GHS, just above the MCT, the rocks record the highest pure shear component (53$48 \%$ pure shear). Jessup et al. (2006) concluded that flow was spatially and temporally partitioned. High temperature samples recorded the early stages of channel flow/extrusion at mid-crustal depths, whereas structurally higher, lower temperature samples recorded subsimple shear flow at the upper margin of the channel during later stages of exhumation. The pure shear component observed in rocks just above the MCT was postulated to be the result of an increase in lithostatic load toward the base of the GHS. In the Sutlej River, Grasemann et al. (1999) showed that orthogneiss mylonites 
within the MCT zone recorded vorticity values close to simple shear for earlier hightemperature deformation and an increasing component of pure shear for later, lowtemperature deformation. In contrast to Jessup et al.'s (2006) interpretation that flow was spatially and temporally partitioned, Grasemann et al. (1999) suggested their vorticity data indicated that the flow regime was temporally partitioned following a decelerating strain path. In Mabja Dome, flow was rheologically partitioned, with vorticity values close to simple shear recorded in quartzites, the mechanically weakest layers (Lister and Williams, 1983). Unlike the studies in the Everest and Sutlej River regions, evidence for a temporal partitioning of vorticity was not observed.

Based on field and structural data from the Kangmar and Mabja domes, and strain compatibility arguments, Lee et al. $(2000,2006)$ suggested that normal slip along the STDS merged at depth into a zone of ductile shear that terminated into a mid-crustal root zone of bulk coaxial strain. Here, rheologically weakened mid-crustal rocks, now exposed in the cores of the domes, were vertically thinned and horizontally stretched resulting in the development of the subhorizontal D2 fabrics. Based on this work, chloritoid-zone rocks in Mabja Dome underwent both top-north and top-south shear within a relatively narrow STDS root zone. Garnet-zone rocks, which are dominantly topsouth, define the transition zone between the root zone of the STDS above and kyanite and deeper rocks, which define the top-south MCT shear zone below. 


\section{CHAPTER V}

\section{CONCLUSIONS}

New detailed microscopic kinematic analyses, deformation temperature estimates, and vorticity analyses within middle crustal rocks from Mabja Dome show a downward progression from both top-north and top-south shear in chloritoid-zone rocks, dominantly top-south shear in garnet- and kyanite-zone rocks, and solely top-south shear in staurolite-zone and deeper rocks. The schists and orthogneisses record general shear deformation $\left(W_{\mathrm{m}}=0.33-0.82,77-38 \%\right.$ pure shear $)$ with an increasing component of pure shear with structural depth. Quartzites record simple shear. A combination of mineral assemblages, microstructures, and quartz fabrics indicates that deformation temperatures during flow ranged from $\sim 450{ }^{\circ} \mathrm{C}$ in chloritoid-zone rocks to $\sim 700{ }^{\circ} \mathrm{C}$ in sillimanite-zone rocks and overlap with published peak metamorphic temperature estimates. These data indicate that vorticity recorded in these rocks formed during peak metamorphism, implying that these fabrics formed in the middle crust between $\sim 35$ and $\sim 16 \mathrm{Ma}$. The chloritoid-zone rocks may have undergone both top-north and top-south shear within a relatively narrow STDS root zone. Garnet-zone rocks, which are dominantly top-south, define the transition zone between the root zone of the STDS above and kyanite and deeper rocks below, which define the top-south MCT shear zone. The deformational patterns in Mabja Dome rocks show that the mid-crustal rocks experienced southward ductile extensional flow within the mid-crustal channel. However, flow is more complex than predicted by channel flow/extrusion models proposed for the Himalayan orogeny. Middle crustal rocks in Mabja Dome preserve evidence for a more complex ductile flow 
regime involving: (1) an increase in the pure shear component within schists and orthogneisses with depth that was the consequence of an increasing lithostatic load; (2) partitioning of the simple shear component into quartzites, the mechanically weakest layers; and (3) mixed top-north and top-south shear at the highest structural levels that most likely reflects spatial variations in flow direction as a result of top-south shear along the MCT and variations in viscosity. 


\section{REFERENCES}

Aoya, M., Wallis, S.R., Terada, K., Lee, J., Kawakami, T., Wang, Y., and Heizler, M., 2005, North-south extension in the Tibetan crust triggered by granite emplacement: Geology, v. 33, p. 853-856.

Aoya, M., Wallis, S.R., Kawakami, T., Lee, J., Wang, Y., and Maeda, H., 2006, The Malashan gneiss dome in south Tibet: comparative study with the Kangmar dome with special reference to kinematics of deformation and origin of associated granites, in Law, R.D., Searle, M.P., and Godin, L., eds., Channel flow, ductile extrusion and exhumation in continental collision zones: Geological Society [London] Special Publication 268, p. 471-495.

Armijo, R., Tapponnier, P., Mercier, J., and Han, T., 1986, Quaternary extension in southern Tibet: Field observations and tectonic implications: Journal of Geophysical Research, v. 91, p. 13803-13872.

Beaumont, C., Jamieson, R.A., Nguyen, M.H., and Lee, B., 2001, Himalayan tectonics explained by extrusion of a low-viscosity crustal channel coupled to focused surface denudation: Nature, v. 414, p. 738-742.

Beaumont, C., Jamieson, R.A., Nguyen, M.H., and Medvedev, S., 2004, Crustal channel flows: 1. Numerical models with applications to the tectonics of the HimalayanTibetan orogen: Journal of Geophysical Research, v. 109, p. 1-29.

Beaumont, C., Nguyen, M.H., Jamieson, R.A., and Ellis, S., 2006, Crustal flow modes in large hot orogens, in Law, R.D., Searle, M.P., and Godin, L., eds., Channel flow, ductile extrusion and exhumation in continental collision zones: Geological Society [London] Special Publication 268, p. 91-145.

Brookfield, M.E., 1993, The Himalayan passive margin from Precambrian to Cretaceous: Sedimentary Geology, v. 84, p. 1-35.

Burg, J.P., Brunel, M., Gapais, D., Chen, G.M., and Liu, G.H., 1984, Deformation of leucogranites of the crystalline Main Central sheet in southern Tibet (China): Journal of Structural Geology, v. 6, p. 535-542.

Burg, J.P., and Chen, J.M., 1984, Tectonics and structural zonation of southern Tibet, China: Nature, v. 311, p. 219-223.

Burg, J.P., Leyreloup, A., Girardeau, J., and Chen, G.M., 1987, Structure and metamorphism of a tectonically thickened continental crust: The Yalu Tsangpo suture zone (Tibet): Royal Society of London Philosophical Transactions, v. A321, p. $67-86$. 
Chen, Z., Liu, Y., Hodges, K.V., Burchfield, B.C., and Royden, L.H., Deng, C., 1990, The Kangmar Dome: a metamorphic core complex in southern Xizang (Tibet): Science, v. 250, p. 1552-1556.

Dewane, T.J., Stockli, D.F., Hager, C., Taylor, M., Ding, L., and Lee, J., 2006, Timing of Cenozoic E-W extension in Tangra Yum Co rift, central Tibet: Journal of Asian Earth Sciences, v. 26, p. 133.

Environmental Systems Research Institute, 2005, ArcMap 9.1, [computer software]: Redlands, CA, Environmental Systems Research Institute.

Fielding, E.J., Isacks, B.L., Barazangi, M., and Duncan, C., 1994, How flat is Tibet?: Geology, v. 22, p. 163-167.

Fitz Gerald, J.D., and Stünitz, H., 1993, Deformation of granitoids at low metamorphic grades. I: Reactions and grain size reduction: Tectonophysics, v. 221, p. 269-297.

Fossen, H., and Tikoff, B., 1997, Forward modeling of non-steady-state deformations and the 'minimum strain path': Journal of Structural Geology, v. 19, p. 987-996.

Fossen, H., and Tikoff, B., 1998, Forward modeling of non-steady-state deformations and the 'minimum strain path': Reply: Journal of Structural Geology, v. 20, p. 979981.

Gaetani, M., and Garzanti, E., 1991, Multicyclic history of the northern India continental margin (northwestern Himalaya): American Association of Petroleum Geologists Bulletin, v. 75, p. 1427-1446.

Gansser, A. 1964, Geology of the Himalayas: London, Wiley-Interscience, 289 p.

Garzanti, E., 1999, Stratigraphy and sedimentary history of the Nepal Tethys Himalaya passive margin: Journal of Asian Earth Sciences, v. 17, p. 805-827.

Godin, L., Grujic, D., Law, R.D., and Searle, M.P., 2006, Channel flow, ductile extrusion and exhumation in continental collision zones; an introduction, in Law, R.D., Searle, M.P., and Godin, L., eds., Channel flow, ductile extrusion and exhumation in continental collision zones: Geological Society [London] Special Publication 268, p. 1-23.

Grasemann, B., Fritz, H., and Vannay, J.-C., 1999, Quantitative kinematic flow analysis from the Main Central Thrust Zone (NW-Himalaya, India): implications for a decelerating strain path and the extrusion of orogenic wedges: Journal of Structural Geology, v. 21, p. 837-853. 
Grujic, D., 2006, Channel flow and continental collision tectonics; an overview, in Law, R.D., Searle, M.P., and Godin, L., eds., Channel flow, ductile extrusion and exhumation in continental collision zones: Geological Society [London] Special Publication 268, p. 25-37.

Grujic, D., Hollister, L.S., and Parrish, R.R., 2002, Himalayan metamorphic sequence as an orogenic channel: insight from Bhutan: Earth and Planetary Letters, v. 198, p. $177-191$.

Grujic, D., Martin, C., Davidson, C., Hollister, L.S., Kuendig, R., Pavlis, T.L., and Schmid, S.M., 1996, Ductile extrusion of the Higher Himalayan Crystalline in Bhutan; evidence from quartz microfabrics: Tectonophysics, v. 260, p. 21-43.

Hager, C., Stockli, D.F., Dewane, T.J., and Ding, L., 2006, Episodic Mio-Pliocene rifting in south-central Tibet. Thermochronometric constraints from the Xainza rift: Eos (Transactions, American Geophysical Union), v. 87, p. T34C-02.

Hirth, G., Teyssier, C., and Dunlap, J., 2001, An evaluation of quartzite flow laws based on comparisons between experimentally and naturally deformed rocks: International Journal of Earth Sciences, v. 90, p. 77-87.

Hirth, G., and Tullis, J., 1992, Dislocation creep regimes in quartz aggregates: Journal of Structural Geology, v. 14, p. 145-159.

Hodges, K.V., Hurtado, J.M., and Whipple, K.X., 2001, Southward extrusion of Tibetan crust and its effect on Himalayan tectonics: Tectonics, v. 20, p. 799-809.

Jain, A.K., Kumar, D., Singh, S., Kumar, A., and Lal, N., 2000, Timing, quantification and tectonic modeling of Pliocene-Quaternary movements in the NW Himalaya; evidence from fission track dating: Earth and Planetary Science Letters, v. 179, p. 437-451.

Jessell, M.W., 1987, Grain-boundary migration microstructures in a naturally deformed quartzite: Journal of Structural Geology, v. 9, p. 1007-1014.

Jessup, M.J., Law, R.D., and Frassi, C., 2007, The rigid grain net (RGN): an alternative method for estimating mean kinematic vorticity number $\left(W_{\mathrm{m}}\right)$ : Journal of Structural Geology, v. 29, p. 411-421.

Jessup, M.J., Law, R.D., Searle, M.P., and Hubbard, M.S., 2006, Structural evolution and vorticity of flow during extrusion and exhumation of the Greater Himalayan Slab, Mount Everest Massif, Tibet/Nepal: Implications for orogen-scale flow partitioning, in Law, R.D., Searle, M.P., and Godin, L., eds., Channel flow, 
ductile extrusion and exhumation in continental collision zones: Geological Society [London] Special Publication 268, p. 379-413.

Jiang, D., 1998, Forward modeling of non-steady-state deformations and the 'minimum strain path': Discussion: Journal of Structural Geology, v. 20, p. 975-977.

Kruhl, J.H., 1998, Reply: Prism- and basal-plane parallel subgrain boundaries in quartz: a Microstructural geothermometer: Journal of Metamorphic Petrology, v. 16, p. 142-146.

Law, R.D., 1990, Crystallographic fabrics: a selective review of their applications to research in structural geology, in Knipe, R.J., and Rutter, E.H., eds., Deformation mechanisms, rheology and tectonics: Geological Society [London] Special Publication 54, p. 335-352.

Law, R.D., Searle, M.P., and Simpson, R.L., 2004, Strain, deformation temperatures and vorticity of flow at the top of the Greater Himalayan Slab, Everest Massif, Tibet: Geological Society [London] Journal, v. 161, p. 305-320.

Lee, J., Dinklage, W.S., Hacker, B.R., Wang, Y., Gans, P.B., Calvert, A., Wan, J., Chen, W., Blythe, A., and McClelland, W., 2000, Evolution of the Kangmar Dome, southern Tibet: structural, petrologic, and thermochronologic constraints: Tectonics, v. 19, p. 872-896.

Lee, J., Wang, Y., McWilliams, M., Hourigan, J., Blythe, A., and McClelland, W., 2002, Contraction, extension, and diapirism in Mabja Dome: implications for tectonics of southern Tibet: Geological Society of America Abstracts with Programs, v.34, p. 332 .

Lee, J., Hacker, B., and Wang, Y, 2004, Evolution of North Himalayan gneiss domes: structural and metamorphic studies in Mabja Dome, southern Tibet: Journal of Structural Geology, v. 26, p. 2297-2316.

Lee, J., McClelland, W., Wang, Y., Blythe, A., and McWilliams, M., 2006, OligoceneMiocene middle crustal flow in the southern Tibet: geochronology of Mabja Dome, in Law, R.D., Searle, M.P., and Godin, L., eds., Channel flow, ductile extrusion and exhumation in continental collision zones: Geological Society [London] Special Publication 268, p. 445-469.

Lee, J., and Whitehouse, M.J., 2007, Onset of mid-crustal extensional flow in southern Tibet: Evidence from U/Pb zircon ages: Geology, v. 35, p. 45-48.

Le Fort, P., 1975, Himalayas; the collided range; present knowledge of the continental 
arc: American Journal of Science, v. 275-A, p. 1-44.

Lister, G.S., and Dornsiepen, U.F., 1982, Fabric transitions in the Saxony granulite terrain: Journal of Structural Geology, v. 4, p. 81-93.

Lister, G.S., and Hobbs, B.E., 1980, The simulation of fabric development during plastic deformation and its application to quartzite: the influence of deformation history: Journal of Structural Geology, v. 2, p. 355-370.

Lister, G.S., Paterson, M.S., and Hobbs, B.E., 1978, The simulation of fabric development in plastic deformation and its application to quartzite; the model: Tectonophysics, v. 45, p. 107-158.

Lister, G.S., and Williams, P.F., 1983, The partitioning of deformation in flowing rock masses: Tectonophysics, v. 92, p. 1-33.

Liu, G., and Einsele, G., 1994, Sedimentary history of the Tethyan basin in the Tibetan Himalayas: Geologische Rundschau, v. 82, p. 32-61.

Lloyd, G.E., and Freeman, B., 1994, Dynamic recrystallization of quartz under greenschist conditions: Journal of Structural Geology, v. 16, p. 867-881.

Mainprice, D., Bouchez, J.L., Blumenfeld, P., and Tubia, J.M., 1986, Dominant c slip in naturally deformed quartz; implications for dramatic plastic softening at high temperature: Geology, v. 14, p. 819-822.

Mancktelow, N.S., 1995, Nonlithostatic pressure during sediment subduction and the development and exhumation of high pressure metamorphic rocks: Journal of Geophysical Research, v. 100, p. 571-583.

Means, W.D., Hobbs, B.E., Lister, G.S., and Williams, P.F., 1980, Vorticity and noncoaxiality in progressive deformation: Journal of Structural Geology, v. 2, p. 371378.

Passchier, C.W., 1987, Stable positions of rigid objects in non-coaxial flow: a study in vorticity analysis: Journal of Structural Geology, v. 9, p. 679-690.

Passchier, C.W., and Trouw, R.A.J., 2005, Microtectonics: New York, Springer Berlin Heidelberg, $366 \mathrm{p}$.

Quigley, M., Liangjun, Y., Gregory, C., Corvino, A., Sandiford, M., Wilson, C.J.L., and Xiaohan, L., 2008, U/Pb SHRIMP zircon geochronology and T-t-d history of the Kampa Dome, southern Tibet; implications for tectonic evolution of the North 
Himalayan gneiss domes: Tectonophysics, v. 446, p. 97-113.

Quigley, M., Liangjun, Y., Xiaohan, L., Wilson, C.J.L., Sandiford, M., and Phillips, D., $2006,{ }^{40} \mathrm{Ar} /{ }^{39} \mathrm{Ar}$ thermochronology of the Kampa Dome, southern Tibet; implications for tectonics evolution of the North Himalayan gneiss domes: Tectonophysics, v. 421, p. 269-297.

Ramsay, J.G., and Huber, M.I., 1987, The techniques of modern structural geology volume 2: folds and fractures: London, Academic Press, 700 p.

Rasband, W.S., 2005, ImageJ 1.34, [computer software]: Bethesda, MD, U.S. National Institute of Health.

Ratschbacher, L., Frisch, W., Liu, G., and Chen, C., 1994, Distributed deformation in southern and western Tibet during and after the India-Asia collision: Journal of Geophysical Research, v. 99, p. 19917-19945.

Selverstone, J., 2005, Preferential embrittlement of graphitic schists during extensional unroofing in the Alps: the effect of fluid composition on rheology in lowpermeability rocks: Journal of Metamorphic Geology, v. 23, p. 461-470.

Spear, F., and Menard, T., 1989, Program GIBBS: a generalized Gibbs method algorithm: American Mineralogist, v. 74, p. 942-943.

Stipp, M., Stünitz, H., Heilbronner, R., and Schmid, S.M., 2002a, The eastern Tonale fault zone: a 'natural laboratory' for crystal plastic deformation of quartz over a temperature range from 250 to $700{ }^{\circ} \mathrm{C}$ : Journal of Structural Geology, v. 24, p. $1861-1884$.

Stipp, M., Stünitz, H., Heilbronner, R., and Schmid, S.M., 2002b, Dynamic recrystallization of quartz: correlation between natural and experimental conditions, in De Meer, S., Drury, M.R., De Bresser, J.H.P., and Pennock, G.M., eds., Deformation mechanisms, rheology and tectonics: Current status and future perspectives: Geological Society [London] Special Publications 200, p. 171-190.

Stockli, D.F., Taylor, M., Yin, A., Harrison, T.M., D’Andrea, J., Lin, D., and Kapp, P., 2002, Late Miocene-Pliocene inception of E-W extension in Tibet as evidenced by apatite (U-Th)/He data: Geological Society of America Abstracts with Programs, v. 34, p. 411.

Tullis, J., Christie, J.M., and Griggs, D.T., 1973, Microstructures and preferred orientations of experimentally deformed quartzites: Geological Society of America Bulletin, v. 84, p. 297-314. 
Tullis, J., and Yund, R., 1992, The brittle-ductile transition in feldspar aggregates; an experimental study, in Evans, B., and Wong, T.F., eds., Fault mechanics and transport properties in rocks: New York, Academic Press, p. 89-118.

Turcotte, D., and Schubert, G., 2002, Geodynamics: New York, Cambridge University Press, $456 \mathrm{p}$.

Vannay, J.-C., and Grasemann, B., 1998, Inverted metamorphism in the High Himalaya of Himachal Pradesh (NW India): Phase equilibria versus thermobarometry: Schweizerische Mineralogische und Petrographische Mitteilungen, v. 78, p. 107132.

Vannay, J.-C., and Grasemann, B., 2001, Himalayan inverted metamorphism and synconvergence extension as a consequence of a general shear extrusion: Geology Magazine, v. 138, p. 253-276.

Wallis, S.R., 1995, Vorticity analysis and recognition of ductile extension in the Sanbagawa belt, SW Japan: Journal of Structural Geology, v. 17, p. 1077-1093.

Wallis, S.R., Platt, J.P., and Knott, S.D., 1993, Recognition of syn-convergence extension in accretionary wedges with examples from the Calabrian Arc and the Eastern Alps: American Journal of Science, v. 293, p. 463-495.

Wenk, H.R., Canova, G., Molinari, A., and Kocks, U.F., 1989, Viscoplastic modeling of texture development in quartzite: Journal of Geophysical Research, v. 94, p. 17895-17906.

Wu, C., Nelson, K.D., Wortman, G., Samson, S.D., Yue, Y., Li, J., Kidd, W.S.F., and Edwards, M.A., 1998, Yadong cross structure and South Tibetan Detachment in the east central Himalaya $\left(89^{\circ}-90^{\circ} \mathrm{E}\right)$ : Tectonics, v. 17 , p. $28-45$.

Xypolias, P., and Koukouvelas, I.K., 2001, Kinematic vorticity and strain rate patterns associated with ductile extrusion in the Chelmos Shear Zone (External Hellenides, Greece): Tectonophysics, v. 338, p. 59-77.

Zhang, H., Harris, N., Parrish, R., Kelley, S., Zhang, L., Rogers, N., Argles, T., and King, J., 2004, Causes and consequences of protracted melting of the mid-crust exposed in the North Himalayan antiform: Earth and Planetary Science Letters, v. 228, p. 195-212. 


\section{APPENDIX}

Rigid Grain Net Plots

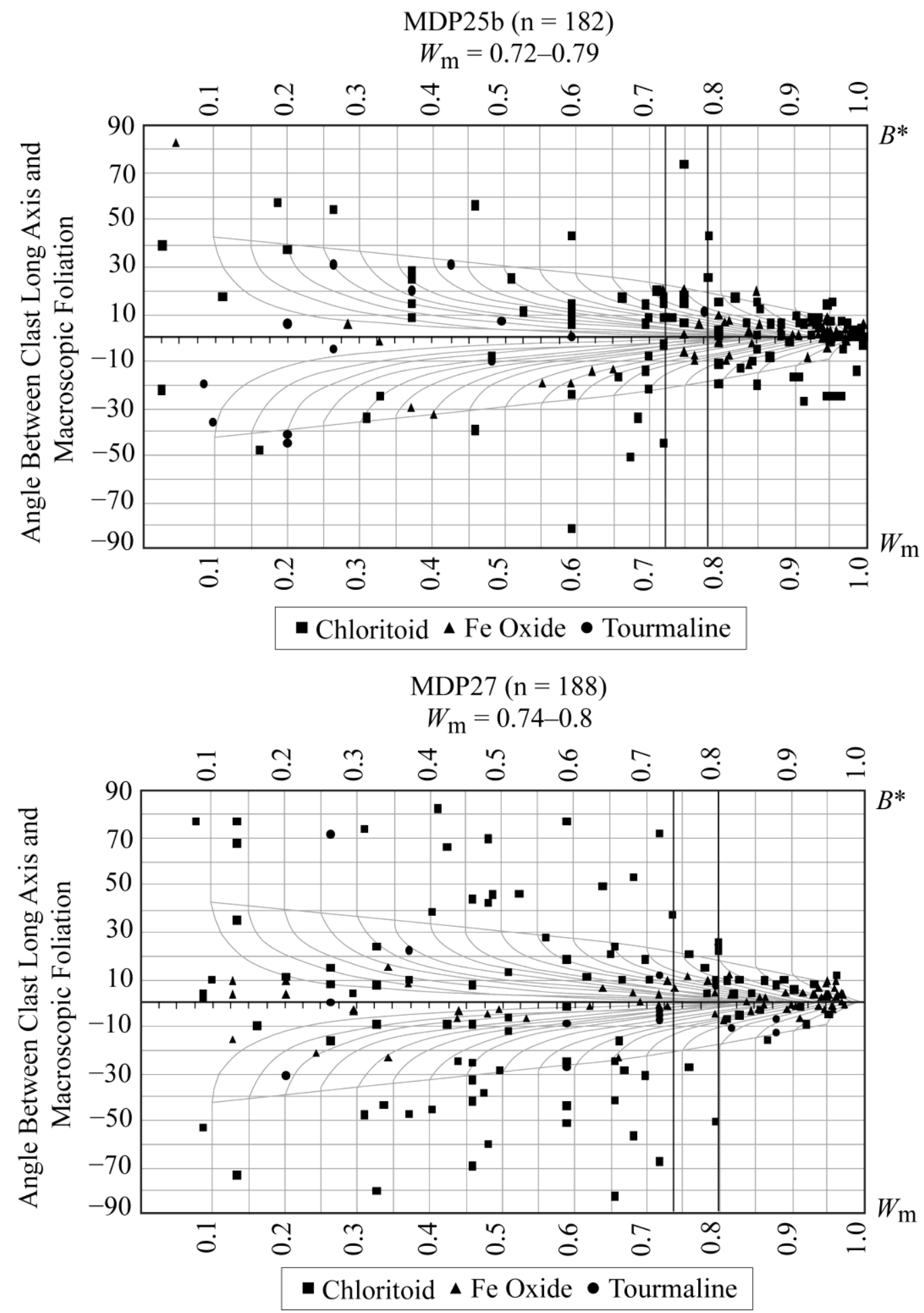



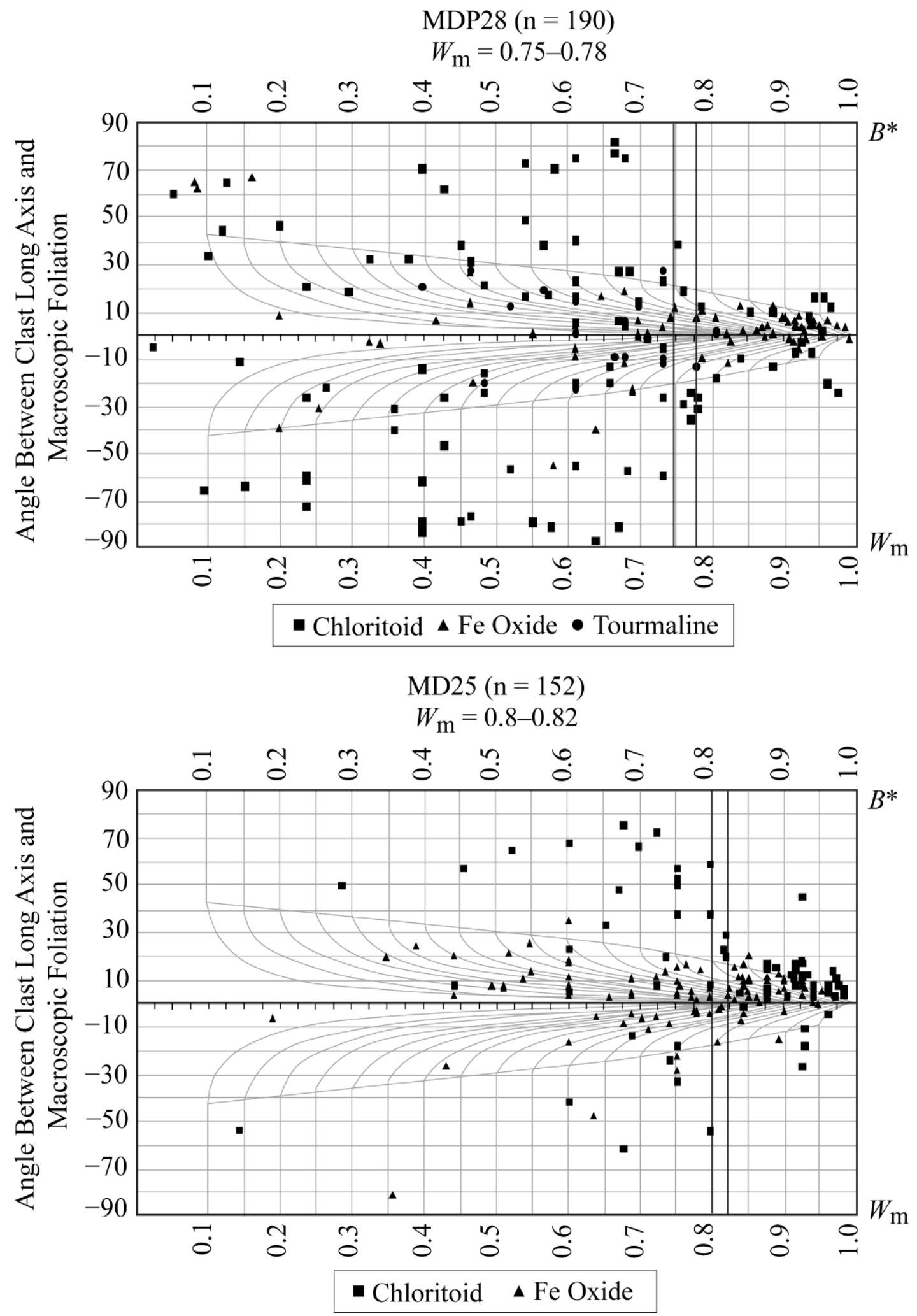


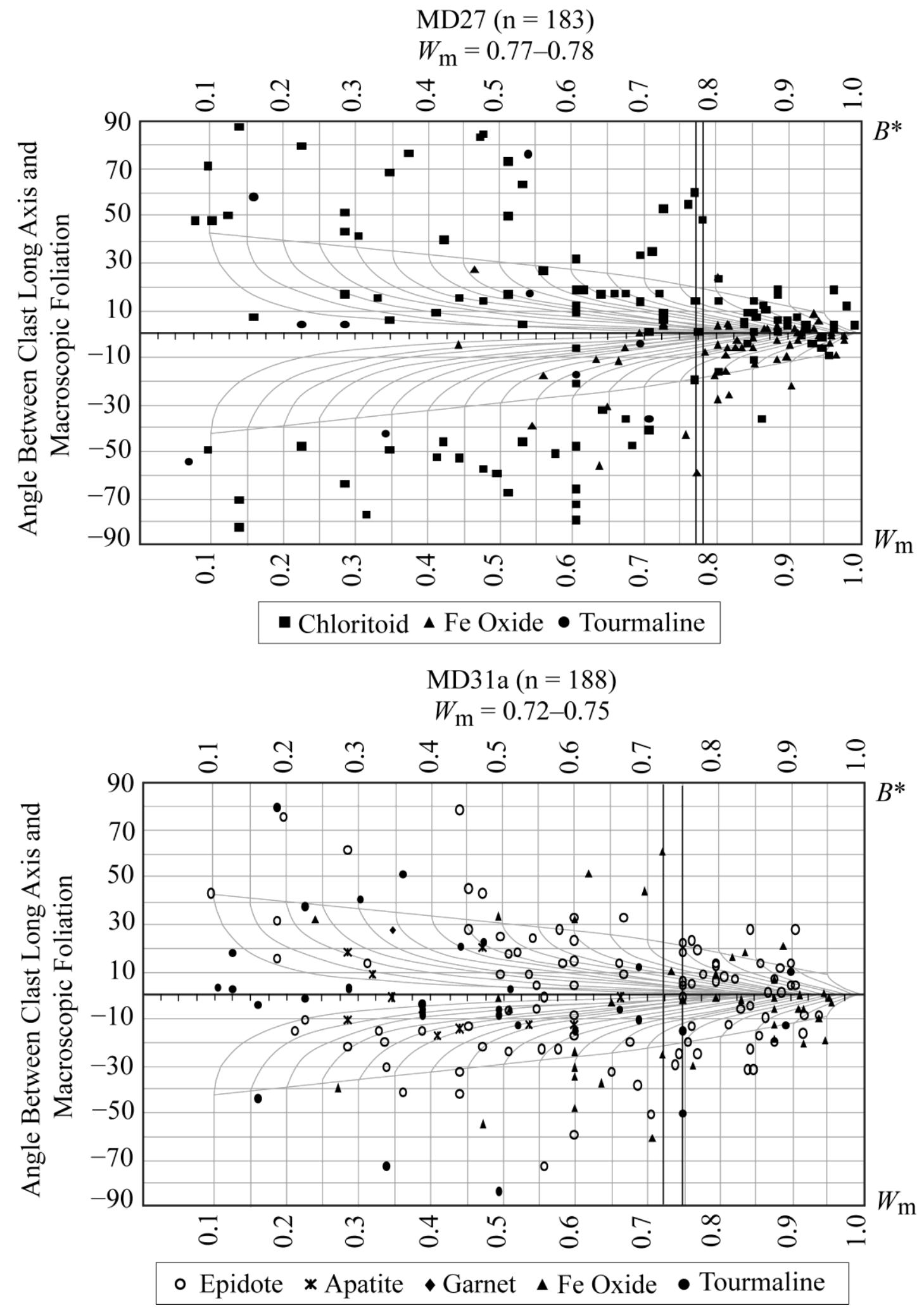



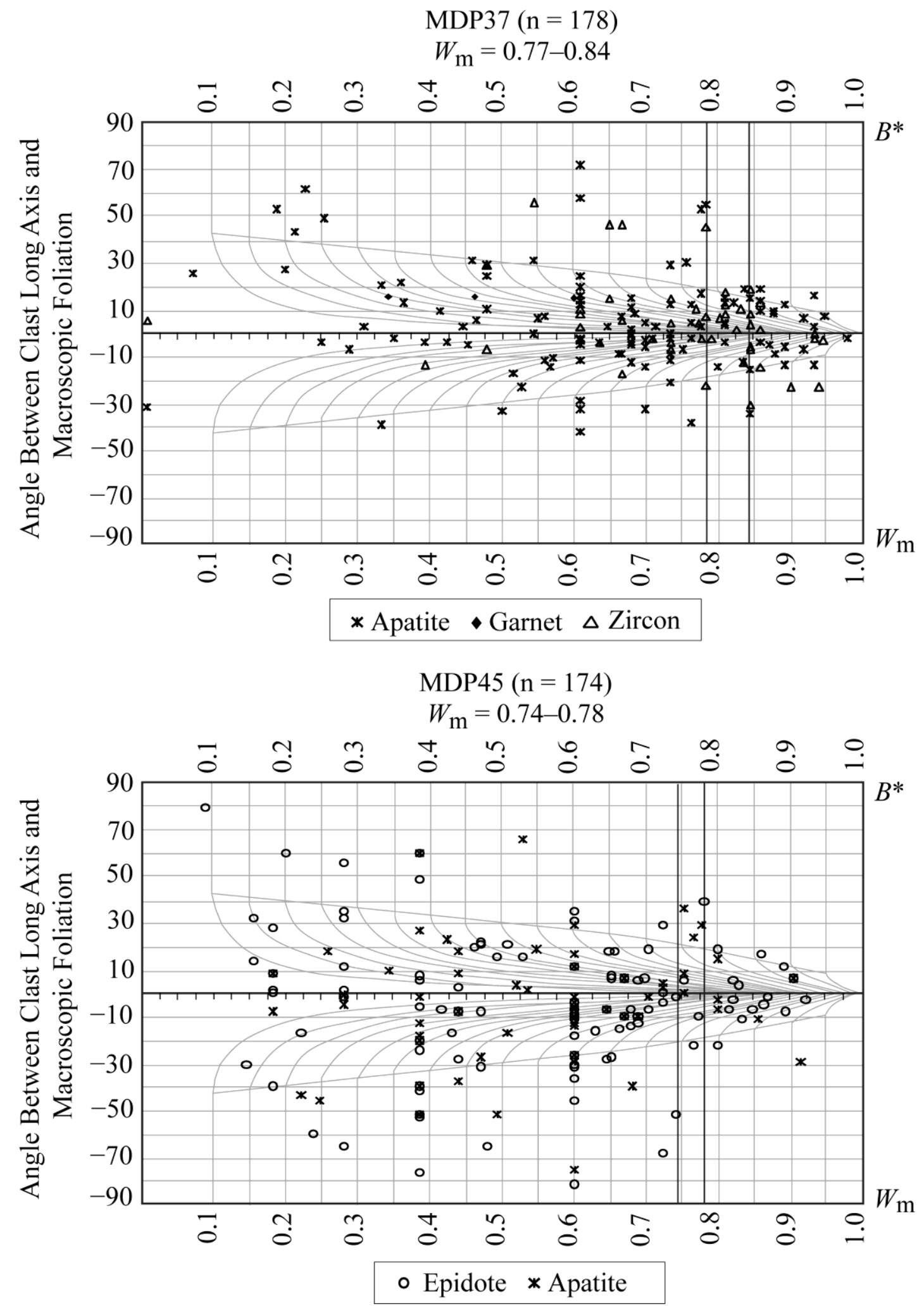

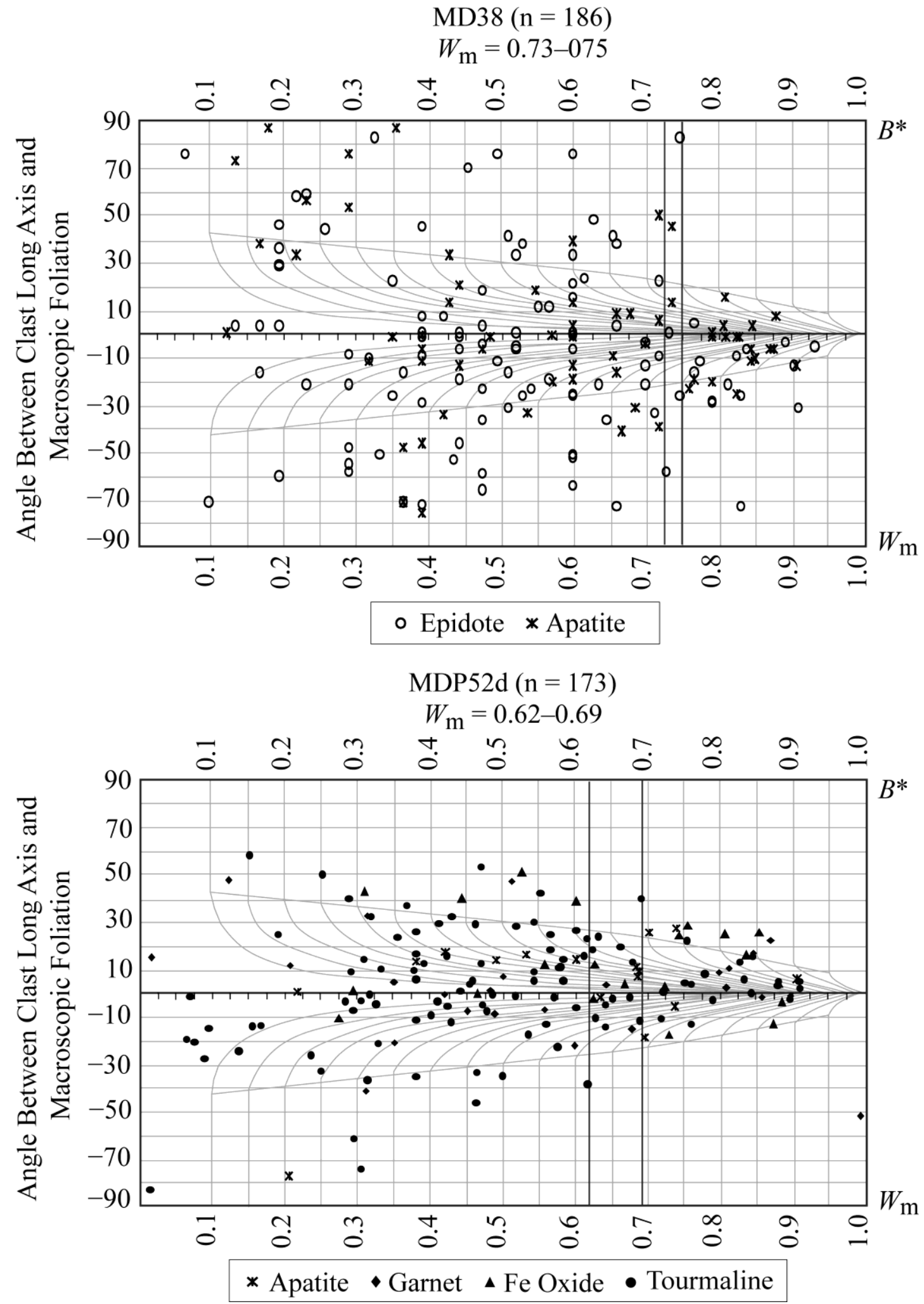


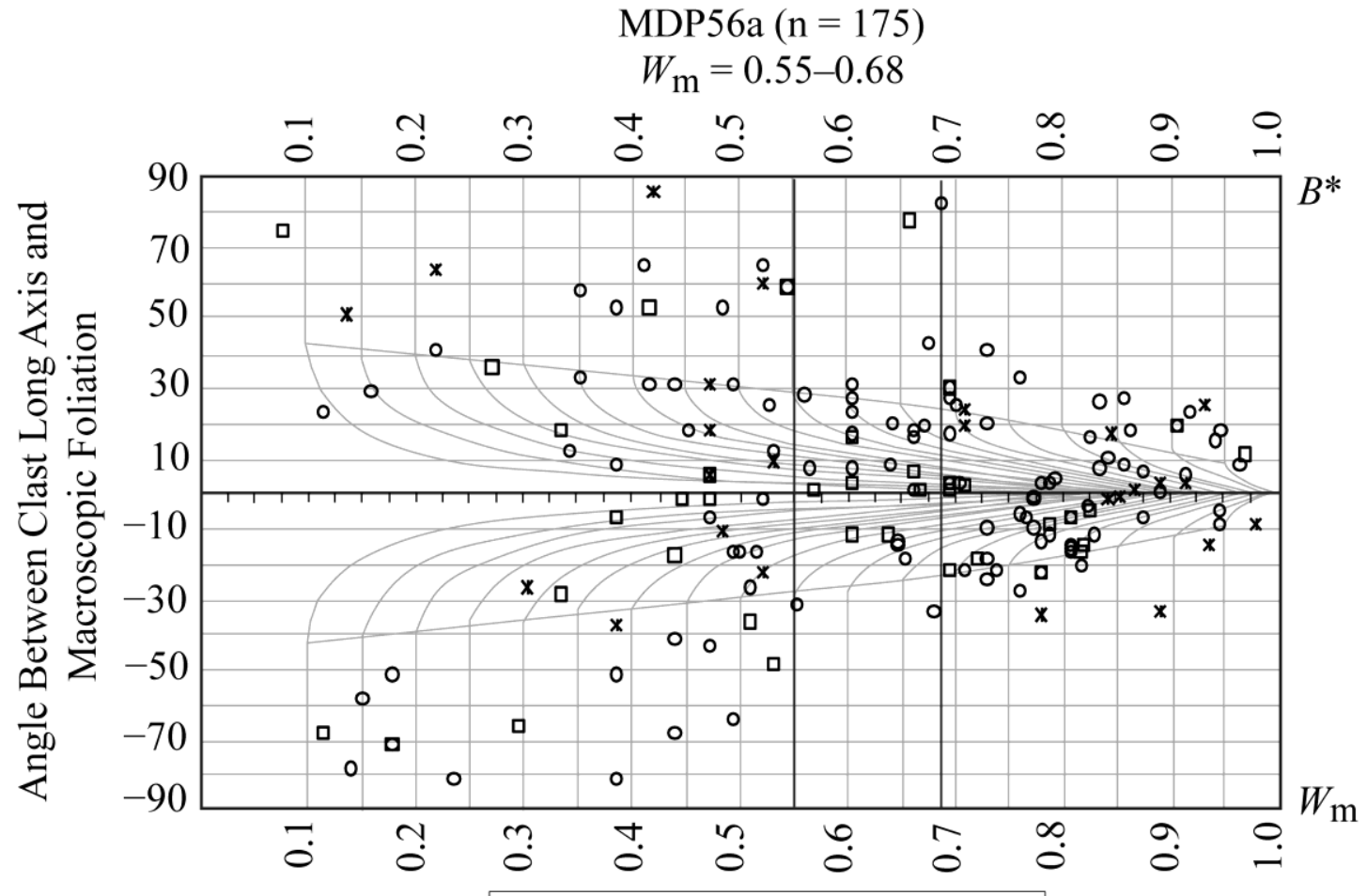

* Apatite $\circ$ Epidote $\square$ Sphene

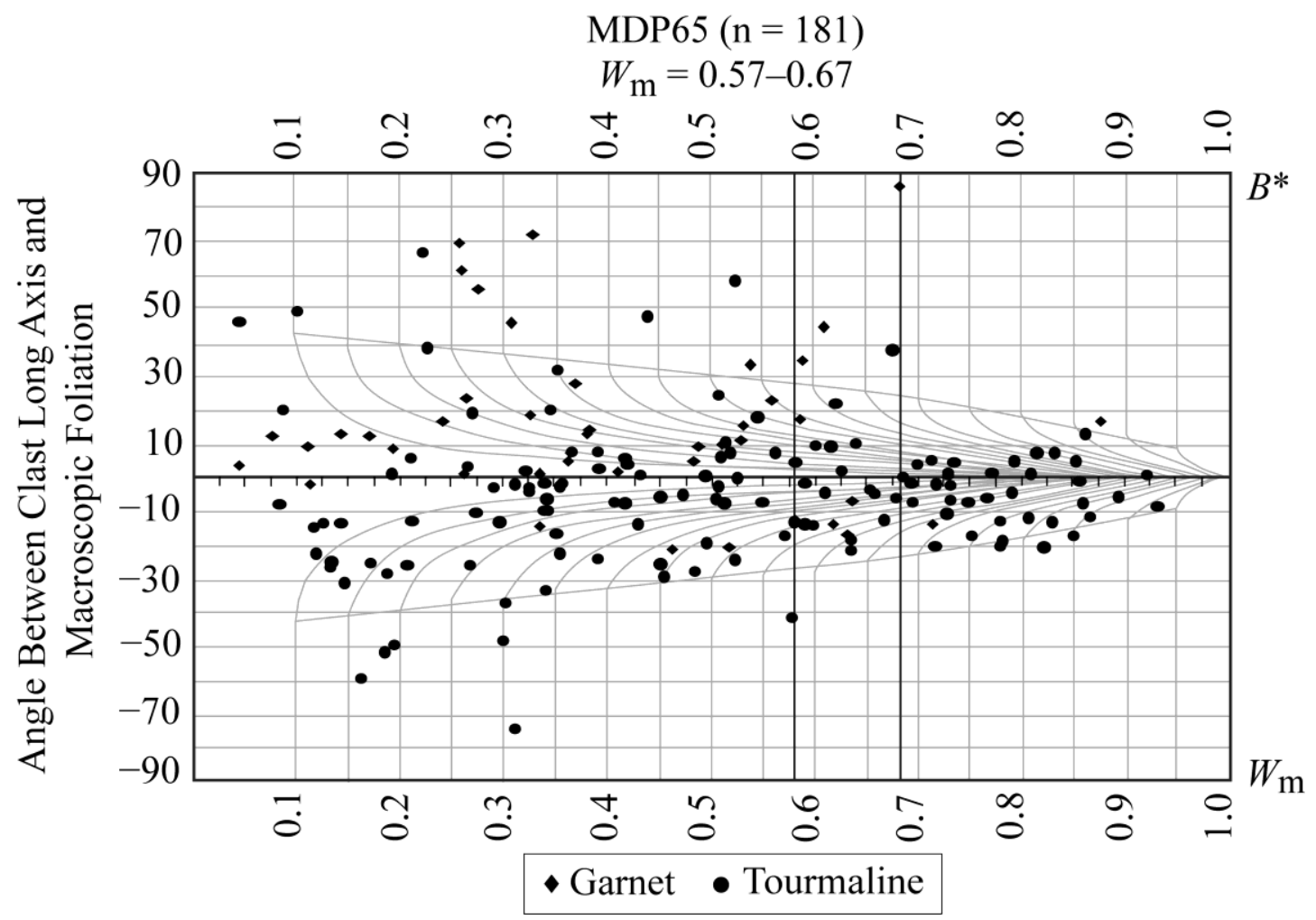



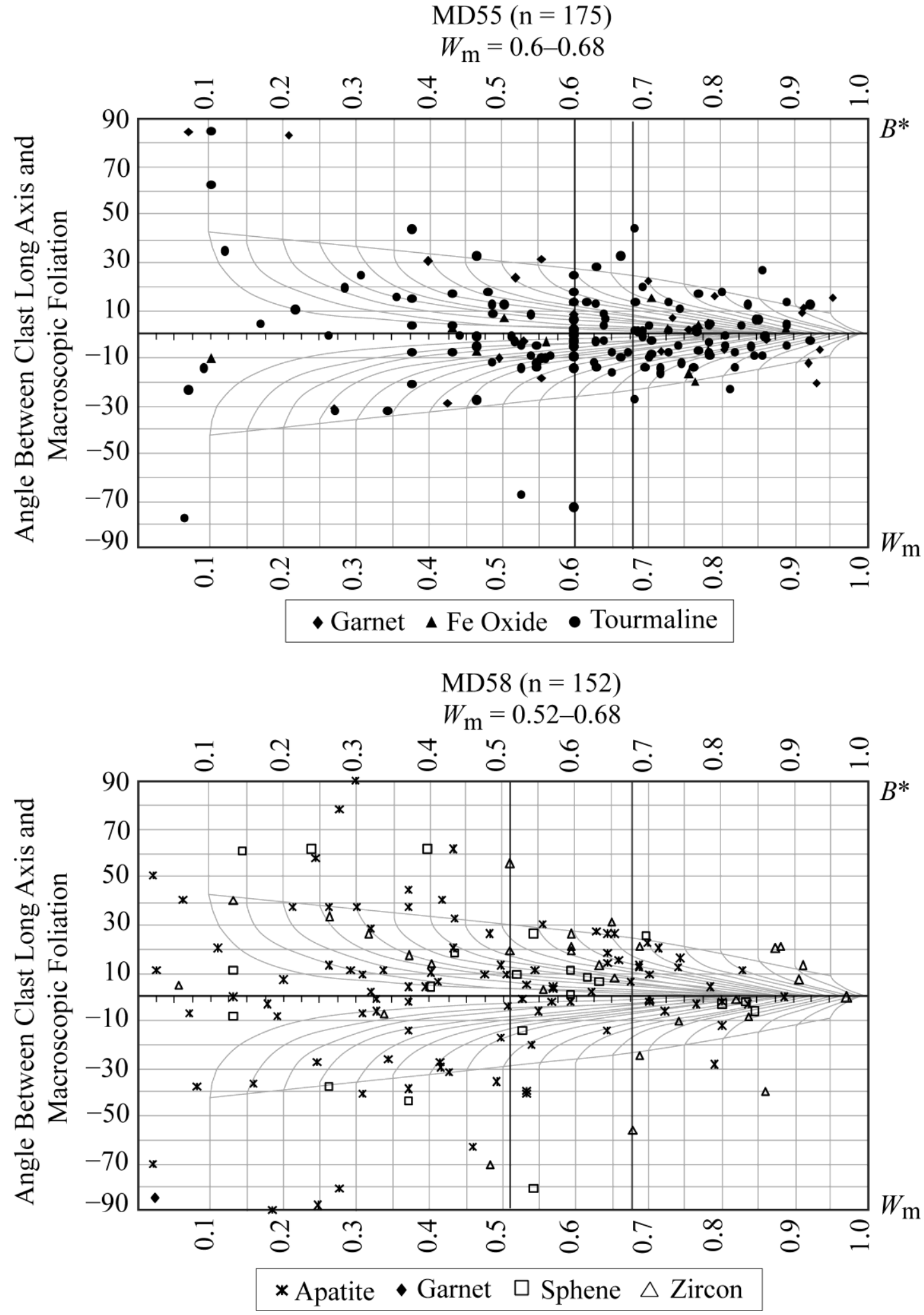


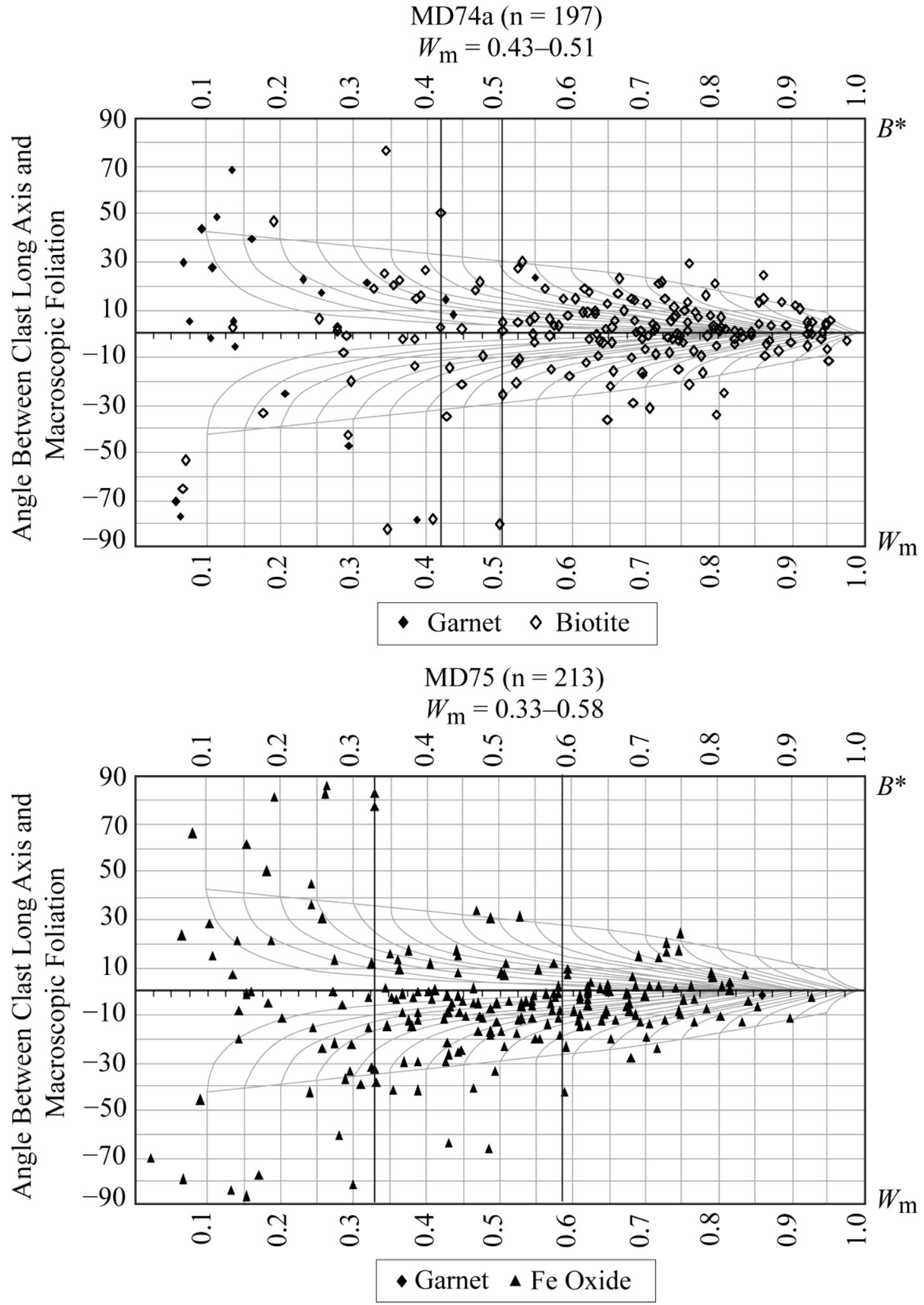



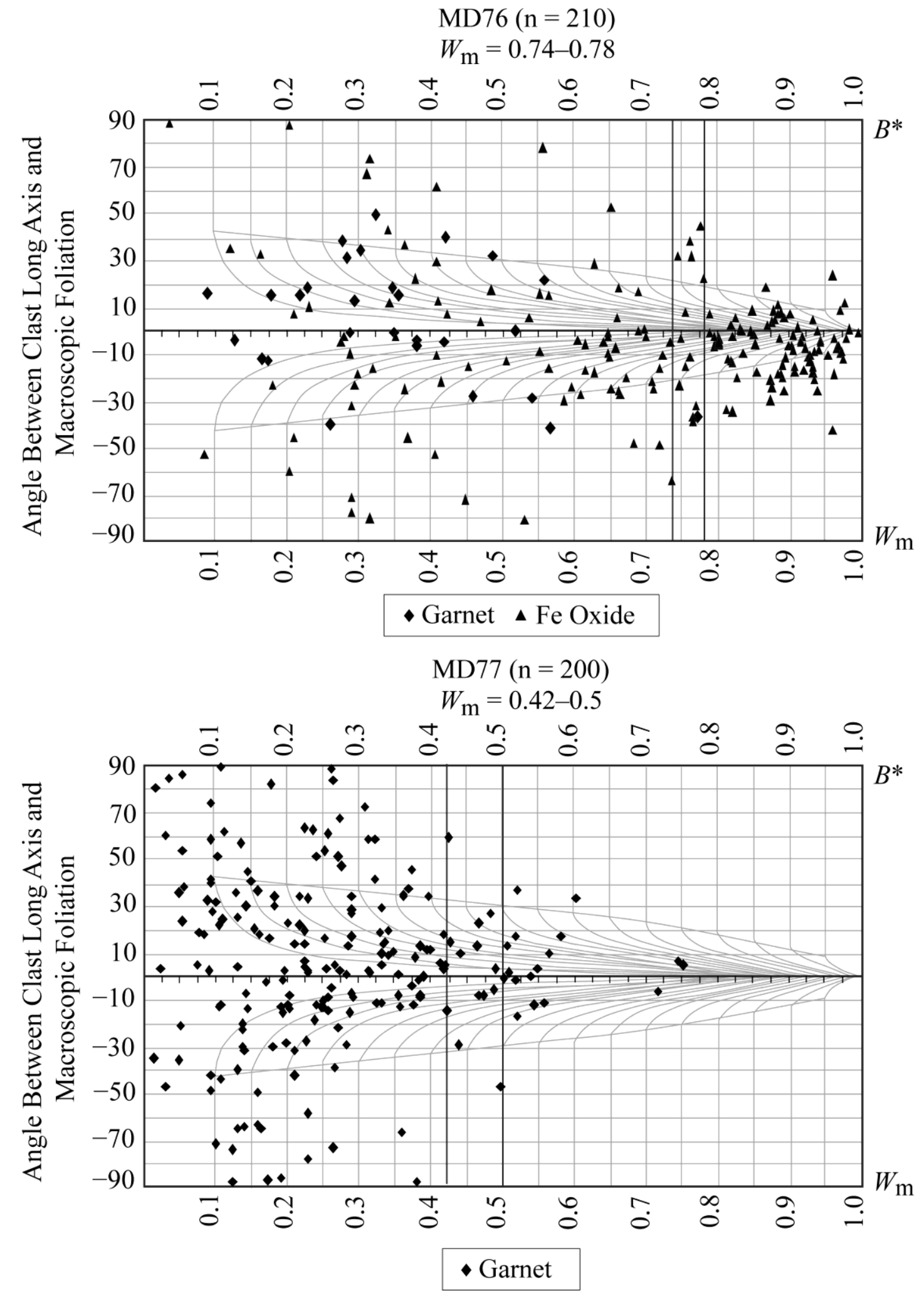

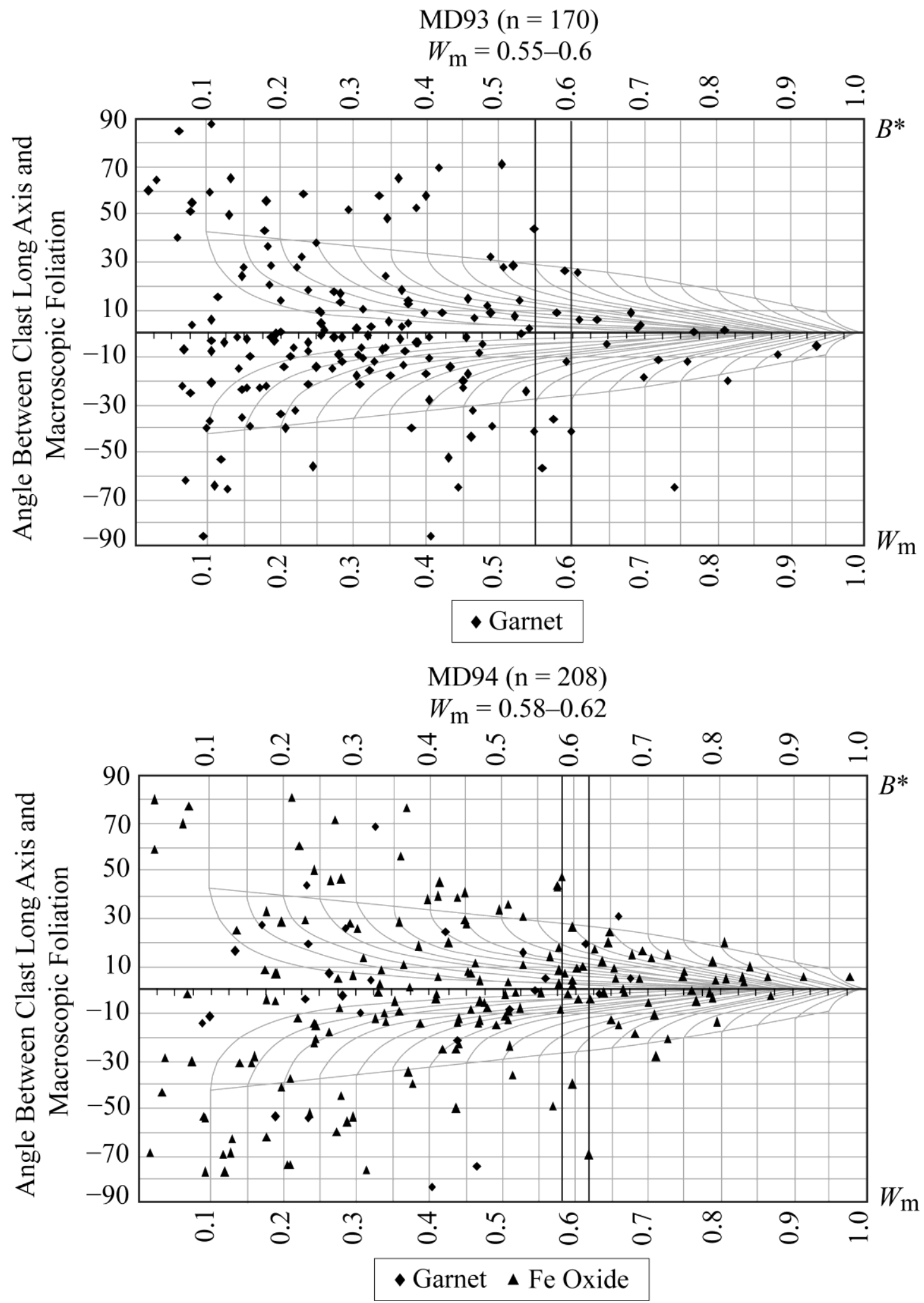

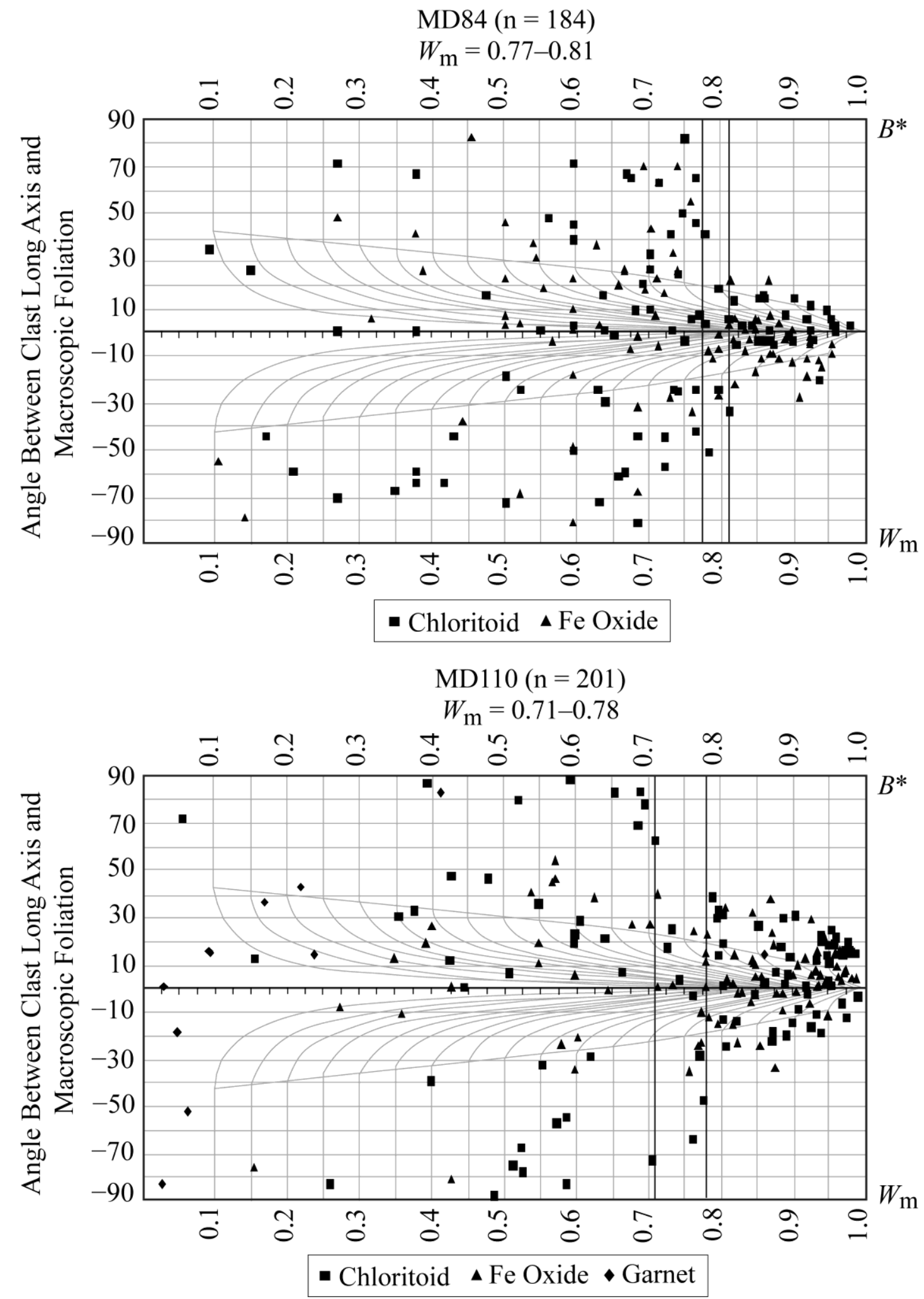

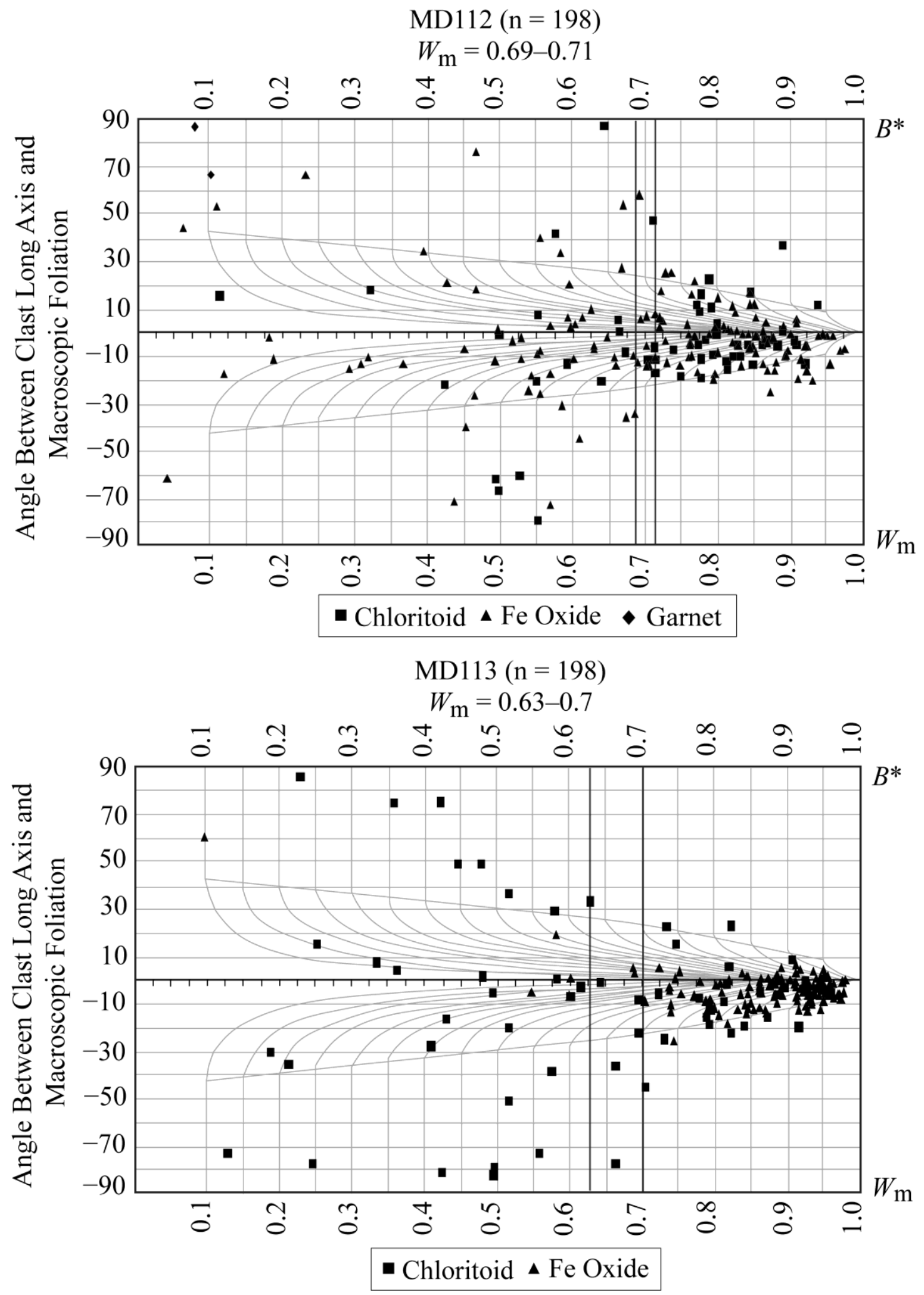